\title{
Research
}

\section{A Case for Developing Place-Based Fire Management Strategies from Traditional Ecological Knowledge}

\author{
$\underline{\text { Lily A. Ray }}^{1,2}$ Crystal A. Kolden $^{3}$, and F. Stuart Chapin III ${ }^{4}$
}

\begin{abstract}
Sustainability science promotes place-based resource management because natural processes vary among ecosystems. When local science is limited, land managers may be forced to generalize from other ecosystems that function differently. One proposed solution is to draw upon the traditional ecological knowledge that indigenous groups have accumulated through resource use. Integrating traditional ecological knowledge with conventional resource management is difficult, especially when the two offer competing explanations of local environments. Although resource managers may discount traditional ecological knowledge that contradicts conventional resource management, we investigate the possibility that these disagreements can arise when nonlocal resource management generalizations displace place-based science. Specifically, we compare claims about wildfires made by Athabascan forest users residing in or near the Koyukuk National Wildlife Refuge and in the U.S. Fish and Wildlife Service fire management plan for that refuge. We focus on two aspects of fire ecology and management: the drivers of landscape flammability and the feasibility of using wildfires and prescribed burns to achieve resource management objectives. The results indicated that some disagreements came from reliance of the federal fire management plan on generalized national narratives at the expense of place-based science. We propose that in some cases, conflicts between traditional ecological knowledge and conventional resource management, rather than indicating a dead end, can identify topics requiring in-depth, place-based research.
\end{abstract}

Key Words: Alaska; climate change; indigenous knowledge; traditional ecological knowledge; wildfire

\section{INTRODUCTION}

Place-based science and traditional ecological knowledge Ostrom and colleagues argue that panaceas, defined as popular solutions prescribed for diverse environmental problems, are doomed to fail because they simplify complex environmental systems, assume homogeneous human resource use, and ignore local context (Ostrom et al. 2007). Diverse research supports these claims: resource management studies caution against universal solutions, as different environments require different management strategies, and resilience studies recognize that general approaches often fail to address the complexities of real ecosystems (Holling 1978, Quigley and Bigler Cole 1997, Berkes and Folke 1998). Sustainability science generally calls for place-based assessments precisely because the complexity of coupled human-environment systems gives rise to such different outcomes by locale (Kates et al. 2001).

The problem of national narratives and the need for placebased science is evident in U.S. wildfire management. Federal fire management agencies followed a national narrative promoting full fire suppression from 1910 to 1968, before recognizing wildfire's ecological importance and embracing fire use as a landscape agent (Stephens and Ruth 2005, Pyne 2010). National narratives now assert that increasing forest density drives landscape flammability and promote uniform risk reduction through prescribed fire and mechanical thinning
(Schoennagel et al. 2004, Stephens and Ruth 2005), failing to recognize place-based, local fire regime characteristics and regional climate change impacts.

In Alaska, for example, place-based research contradicts the national policy narrative. Unlike the fuel-limited fire regimes of the southwestern U.S. pine forests, which historically burned frequently at low intensity (Westerling et al. 2003), Alaskan ecosystems burn under infrequent summer drought (Abatzoglou and Kolden 2011) and with stand-replacing severity, taking decades to regenerate after fire (Chapin et al. 2006). In addition to inaccessibility, this long regeneration period impedes monitoring of landscape flammability and wildfire effects. Although regional studies exist, Alaska's size and diverse terrain challenge local application to remote areas, as even small differences in climate and topography can lead to different wildfire patterns (Kasischke and Turetsky 2006, Kane et al. 2007, Johnstone et al. 2010) Resource managers are thus challenged to gather the local information needed for comprehensive, place-based management. One potential solution is to draw on traditional ecological knowledge, or TEK, defined by Berkes et al. (2000:1252) as:

a cumulative body of knowledge, practice, and belief, evolving by adaptive processes and handed down through generations by cultural transmission, about the relationship of living beings (including humans) with one another and with their environment.

${ }^{1}$ Department of Geography, Clark University, ${ }^{2}$ Resilience and Adaptation Program, University of Alaska, Fairbanks, ${ }^{3}$ Department of Geography, University of Idaho, ${ }^{4}$ Institute of Arctic Biology, University of Alaska, Fairbanks 
Fortunately for Alaskan resource managers, indigenous Alaskan residents depend on the boreal forest and regularly observe forest processes (Nelson 1983, Marcotte 1986, 1990). Considerable research indicates that TEK could fill gaps in resource management science (Acheson et al. 1998, Kofinas et al. 2002, Krupnik and Jolly 2002, Berkes 2008, Alexander et al. 2011) and that management devoid of traditional ecological knowledge and values will be neither ecologically sustainable nor locally acceptable (Osherenko 1988, Rocheleau et al. 1996; Acheson et al. 1998, Holling et al. 1998, Kofinas et al. 2002, Tsing et al. 2005; Berkes 2007, Reynolds et al. 2007). In practice, however, integrating TEK with conventional resource management is difficult (Gilchrist et al. 2005, Fernandez-Gimenez et al. 2006). TEK rarely fits neatly into scientific models, as resource managers and indigenous resource users often perceive environmental issues differently, and some indigenous resource users may refuse to generalize about natural processes because their knowledge is placebased (Berkes 1987, Cruikshank 2000, Huntington 2000, Watson and Huntington 2008). The integration of TEK and resource management science is particularly difficult when the two contradict each other and has therefore received less attention in the literature (Rist et al. 2010).

Although contradictions between TEK and resource management sometimes bring new insight into management questions (e.g., Huntington 2000, Rist et al. 2010), conflicts between the two knowledge types frequently derail collaboration. In many cases, researchers or managers may use Western science to validate TEK (Fernandez-Gimenez et al. 2006), pronouncing TEK incorrect if it contradicts resource management science (e.g., Gilchrist et al. 2005). Although incorrect or incompatible TEK may account for some disagreements, an understudied alternative is that the inappropriate application of generalized national narratives to local environments may also generate conflict between TEK and resource management. In this study we evaluate federal wildfire management policies and the TEK of Koyukon Athabascan resource users for areas of agreement and conflict. We compare these results with national policy narratives and regional fire ecology research to determine whether regional scientific understanding of fire ecology corresponds more closely to national narratives or to regional TEK and if, in areas of knowledge conflict, management policies follow national policy narratives rather than regionally specific knowledge. We focus on two elements of fire ecology and management: drivers of landscape flammability and the use of wildfire as a management tool.

\section{Drivers of landscape flammability}

Increasing evidence in the late $20^{\text {th }}$ century indicated that a century of intense wildfire suppression in the western U.S. had removed a natural counterbalance to growth and produced "overstocked" forests (Arno and Allison-Bunnell 2002, Brown et al. 2004). In 2000, this observed trend contributed to catastrophic wildfires that burned across the western U.S and inspired a national approach for reducing wildfire risk (Machlis et al. 2002). The Healthy Forests Initiative (HFI) of 2002 and the Healthy Forests Restoration Act (HFRA) of 2003 sought to counter increased wildfire hazard by reducing forest fuel loading and restoring historic stand structure (White House 2002).

Although this national policy narrative was applied uniformly, the supporting science came primarily from pine forests in the southwestern U.S. Subsequent work found that infrequent, high intensity wildfires occur naturally in other ecosystems that are not overstocked; instead, their flammability has been relatively unaltered by a century of wildfire suppression (Brown et al. 2004, Schoennagel et al. 2004, Platt et al. 2006). Additionally, other research attributed changes in fire behavior to climate change and not fuel loading (Westerling et al. 2006, 2011), challenging connections between fire suppression and fuel abundance (McKenzie et al. 2004, Schoennagel et al. 2004). Despite this counter-narrative demonstrating the importance of local understanding, the national narrative of human-altered forest structure as the primary driver of wildfire risk still pervades fire management strategies (Steelman and Burke 2007).

Over the last three decades support for fire use surged, resulting in national policies supporting both prescribed burning to manage hazardous fuels and wilderness fire as an essential ecological process. This support exists despite evidence that many ecosystems are neither fire-adapted nor do they historically burn with low to moderate severity (Pyne 2001, 2004). Universal support for managed fire may adversely affect wildlife habitat, biodiversity, and productivity in some ecosystems (Tiedemann et al. 2000, Varner et al. 2005), and some suggest a more cautious approach to forest restoration (Tiedemann et al. 2000, Pyne 2001).

\section{Use of TEK for fire management}

The model for using TEK in science-based fire management comes from Australia, where incorporating aboriginal landholders has contributed to more ecologically complete fire management programs (Lewis 1989, Russell-Smith et al. 1997, Petty et al. 2007). In the U.S., fire management has only integrated TEK on a limited basis, despite considerable indigenous TEK of fire regimes (Anderson 2005, Lake 2007, Carroll et al. 2010). In Alaska, most attempts to integrate TEK into management have focused on wildlife, with no comparable effort for wildfire management (McNeeley 2012). Several studies have investigated wildfire effects on rural indigenous resource users, showing that wildfires temporarily complicate subsistence resource use and that rural and urban Alaskans have different vulnerabilities (Chapin et al. 2008, Nelson et al. 2008, Trainor et al. 2009). This research indicates a need for Alaskan wildfire management to incorporate TEK, a gap that this study seeks to fill. 


\section{Study Area}

Galena and Huslia are located, respectively, along the Yukon and Koyukuk rivers in a remote, roadless, and sparsely populated part of western interior Alaska (Nelson 1983). Since 1980, much of this traditional Koyukon Athabascan territory has been managed by the U.S. Fish and Wildlife Service (FWS), which oversees the 1.8 million hectare Koyukuk National Wildlife Refuge (Koyukuk Refuge) and the 304,000 hectare Northern Unit Innoko National Wildlife Refuge (Figure 1). Koyukon culture developed around boreal forest use, and area residents traditionally moved seasonally to harvest resources such as fish, waterfowl, furbearers, and large and small game (Nelson 1983). Although most Koyukon no longer move seasonally, they still depend heavily on wild resources (Marcotte 1986, 1990).

Fig. 1. Study area.

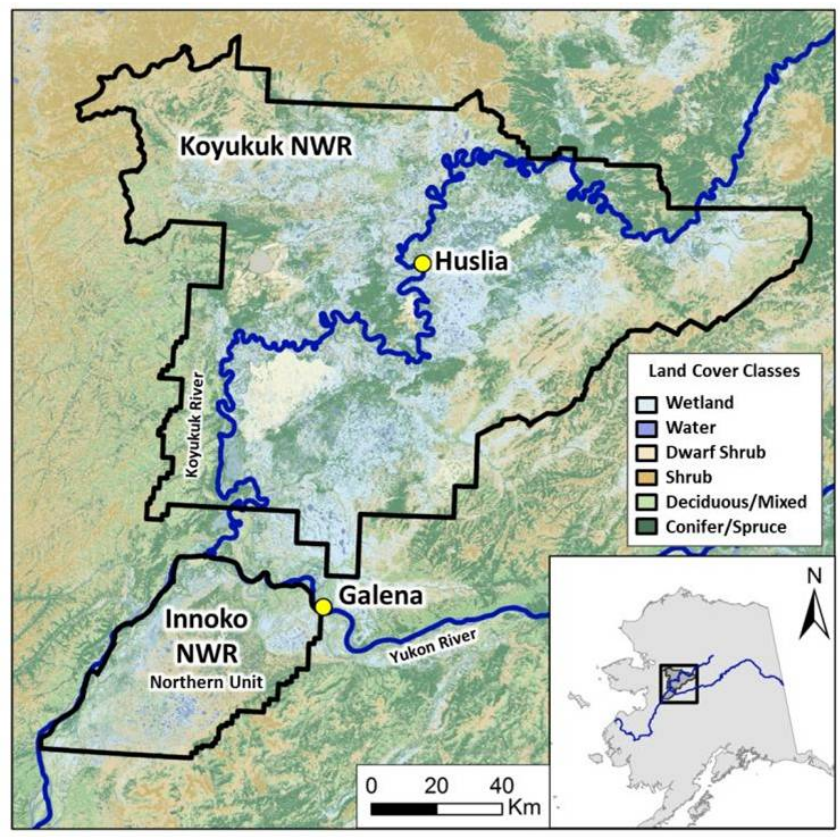

Historical analysis indicates that the Koyukon did not traditionally practice landscape burning, likely because Koyukon territory had natural landscape variability even without wildfires, lower lightning strike density and more moisture than other parts of interior Alaska, and residents with fixed resource use territories (Natcher et al. 2007). Currently, this area is regularly affected by wildfires that generate conflict between local users and federal managers. While the Koyukuk and Northern Unit Innoko National Wildlife Refuge Fire management plan (FMP) (Alaska Region U.S. Fish and Wildlife Service 2005) espouses the ecological benefits of wildland fire, recent research showed that many resident Koyukon saw wildfire as a destructive force, largely due to disruptions to forest access and traditional wild food use
(Huntington et al. 2006, Chapin et al. 2008, Ray 2011). This study builds on that research by collecting detailed, placebased observations of wildfire effects from Koyukon forest users for qualitative comparison with the management objectives laid out in the FMP.

\section{METHODS}

This study uses qualitative methods to document indigenous observations of wildfires and place change on the Koyukuk Refuge, and to compare these to the FMP. Qualitative methods, which allow respondents to introduce information not considered by researchers, are considered most appropriate for documenting perspectives unrepresented in the literature (Auerback and Silverstein 2003). Qualitative analysis uses textual data, such as interview transcripts, to generate datadriven categories, which are generally robust and can be applied to different texts for comparison (Glaser and Strauss 1967). To generate texts describing indigenous observations of wildfires, semi-structured interviews with 43 Koyukon residents of Galena and Huslia were conducted in English, digitally recorded, and transcribed. Traditional ecological knowledge interviews take considerable time, thus preventing a census approach, and random sampling does not produce appropriate respondents (Tashakkori and Teddlie 1998, Wengraf 2001). Consequently, a purposive sampling strategy targeted male $(n=24)$ and female $(n=19)$ residents age 45 and older with extensive forest knowledge.

An interview guide, developed using local feedback, ensured consistency, but question order varied by respondent, and, if respondents introduced a relevant topic that was not on the interview guide, they were encouraged with follow-up questions (Slocum et al. 1995, Huntington 1998, Bernard 2006). Respondents were asked to describe resource use areas they had utilized since childhood and to recount changes they had seen over their lifetimes, both in the characteristics of places and in the availability of subsistence resources. Respondents were then asked if any of these areas burned and how burning affected the place and the resources of interest. Previous research in Huslia showed that general discussions about wildfires can lead to statements that may be difficult to interpret out of context (Huntington et al. 2006). To avoid confusion, project interviews focused on wildfire effects directly observed during subsistence uses of area forests. Interview transcripts were coded in ATLAS.ti for both predetermined and data-generated categories (Marshall and Rossman 1995). This generated lists of quotes organized by category (Appendix 1).

The observations coded to each category were organized into diagrams that maintained respondent descriptions of cause and effect and included the number of respondents reporting each phenomenon (Namey et al. 2008). As respondents had different subsistence use areas with different wildfire histories, interview content varied considerably. 
Fig. 2. Koyukon respondent descriptions of factors influencing wildfire severity and resultant effects on resources. Note that the numbers in parentheses refer to the number of respondents who provided that response.

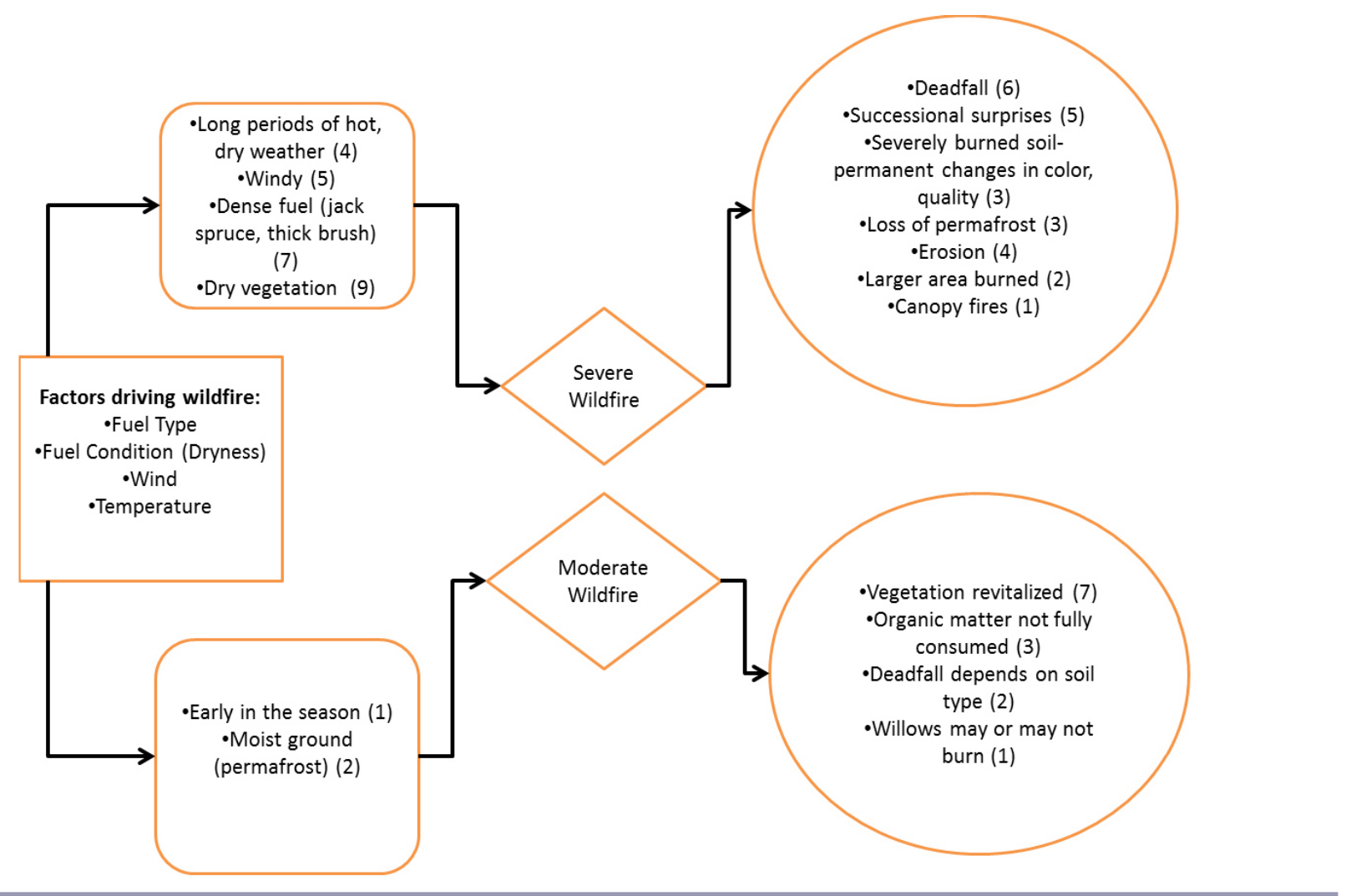

Results were reviewed by participants in an iterative process that involved return visits to Galena and Huslia and mailings. Written summaries of results were presented to respondents in person or by mail in order to solicit feedback. Results were also presented at a community meeting in Huslia and at a tribal council meeting in Galena.

To compare the observations of subsistence users in the Koyukuk Refuge area with local wildfire management policy, we analyzed the FMP using ATLAS.ti (Alaska Region U.S. Fish and Wildlife Service 2005). The FMP was coded to the same categories as the interview transcripts, ensuring data comparability, and coded observations were organized into diagrams comparable with Koyukon response diagrams.

The FMP was developed using a national template published by both FWS and the Department of the Interior that prescribes the exact FMP format (U.S. Fish and Wildlife Service 2008, Department of the Interior 2009). FMPs are generally developed by fire managers, agency planning personnel, or contracted private firms. Fire managers and agency personnel take a required national-level course in the National Interagency Fire Center training system that includes FMP development (Kolden, unpublished manuscript). While local science and data are allowed in FMPs, they are not required. Most preparers do not deviate from the template because the FMP must be approved through the National Environmental Policy Act (NEPA) review process. Finally, the FMP determines how much funding the local unit will receive from the national agency; since the National Fire Plan of 2000, fire managers have prioritized hazardous fuels management because federal funding was tied to reduction of hazardous fuels, particularly near communities (Steelman and Burke 2007, Schoennegal et al. 2009, Kolden and Brown 2010). To our knowledge, this is the first comparison of an FMP to regional knowledge about wildfire.

\section{RESULTS}

\section{Community perspective}

Drivers of landscape flammability General

Although interview questions did not cover wildfire severity, multiple respondents described drivers of landscape flammability in terms of effects on wildfire severity and thus on subsistence resources after a wildfire (Figure 2). The 
Fig. 3. Koyukon respondent observations of changes in landscape and climate influencing wildfire regime. Note that the numbers in parentheses refer to the number of respondents who provided that response.

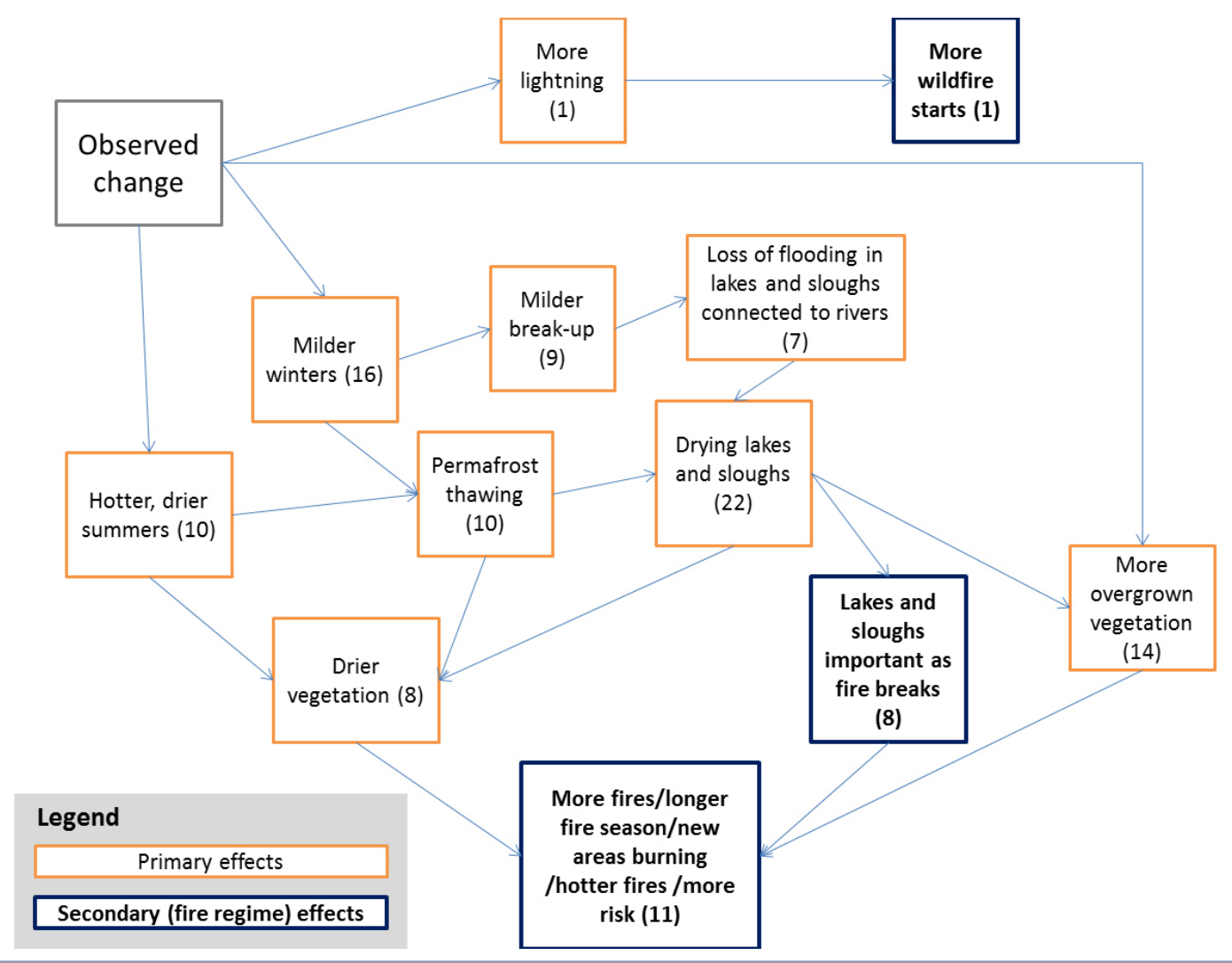

combined responses identified four primary components of landscape flammability: fuel type and condition (moisture), wind, and temperature. Several respondents also recognized two distinct phases of the boreal fire season: the earlier season conditions conducive to moderate severity wildfires and the later season, drier conditions conducive to more severe wildfire activity affecting soil and permafrost. Finally, respondents pointed out both first order (what the fire directly consumed) and second order (long-term successional impacts) fire effects for both levels of fire severity.

Changes in landscape and climate

Numerous respondents had observed changes in both the landscape and climate that increased landscape flammability. The most commonly reported changes included drying lakes and sloughs, milder winters, more overgrown vegetation, hotter drier summers, and thawing permafrost (Figure 3). Many respondents noted both first order effects of climate change (i.e., the timing and magnitude of events) and second order effects (i.e., how climate change is altering the wildfire regime).
Time since wildfire

Interview responses did not indicate consensus on the relationship between flammability and time since last burn. Eight respondents supposed that flammability could increase with time since burn, as dense brush could build up, while six respondents indicated that wildfires caused flammable conditions by killing trees. Most respondents related flammability not to fire history but to specific vegetative conditions caused by different factors (Figure 4). Dead or dry vegetation was seen as the primary cause of flammable conditions, followed by dense brush, grass, and jack spruce (Figure 4).

\section{Fire as a management tool}

Koyukon respondents' primary resource management objectives emphasized traditional subsistence uses and resource health, access, and abundance (Table 1). Residents observed that wildfires dramatically affected subsistence resources and access. Respondents reported both positive and negative effects (Figure 5) but perceived more wildfireinduced hardships than benefits due to downed trees blocking 
Fig. 4. Specific drivers (Column 1) of landscape-scale flammable conditions (Column 2) as reported by Koyukon respondents. Jack spruce refers to small, densely clustered black spruce (Picea mariana). Note that the numbers in parentheses refer to the number of respondents who provided that response.

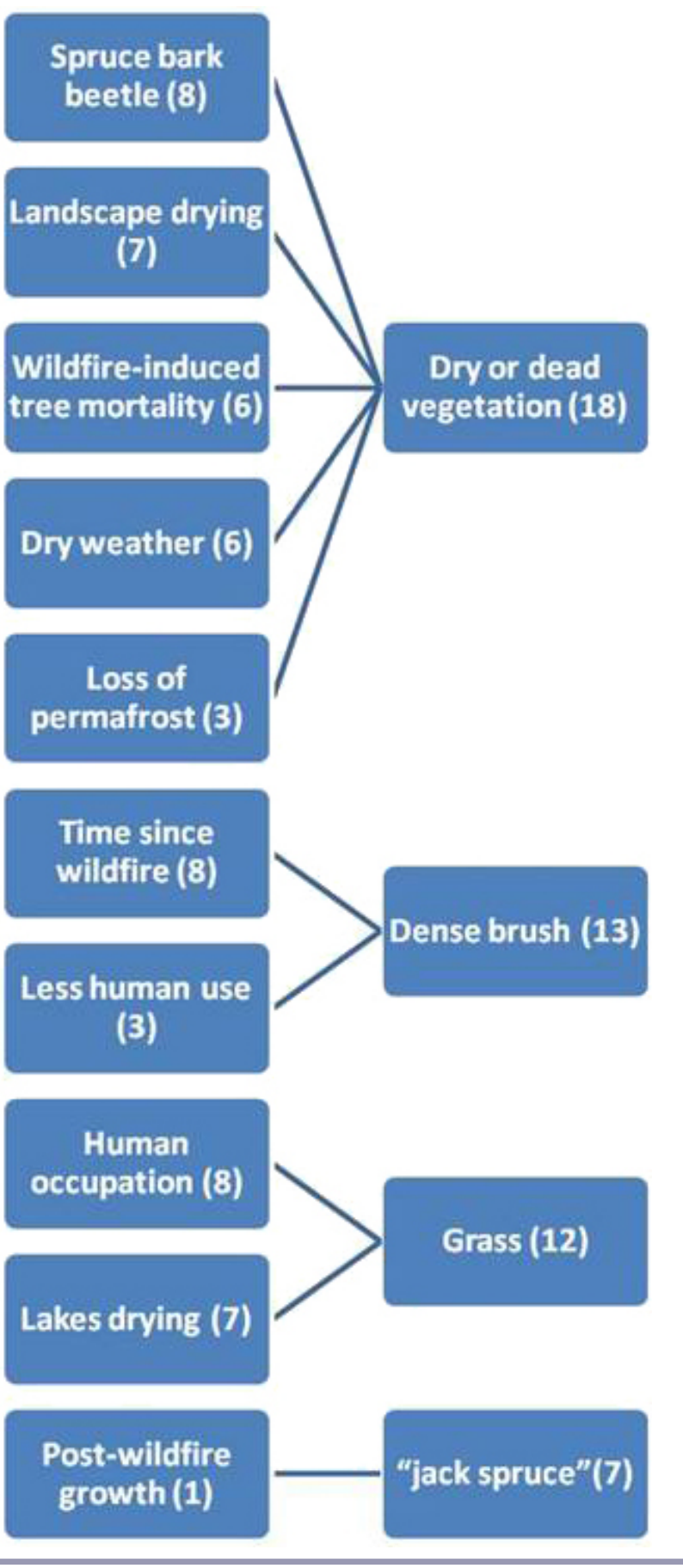

Table 1. Koyukon respondent forest goals.

Primary forest goal: maintain subsistence resources and access in a healthy landscape

Supporting goals:

- Abundance of wildlife, including large game like moose or caribou, furbearers, waterfowl, birds, rabbits, and even mice, lemmings, and bugs to support the food chain

- Accessible trails

- Abundant berries

- Abundant trees, including birch trees

- Wood available for house logs and heating

- Forests and wetlands with sufficient water, trees and plants not drying out

- Maintain permafrost

- Sufficient old-growth forest for shelter, habitat, and beauty

- New growth for animals to eat

- Healthy soil and water, free from pollution

- Lack of infections such as spruce bark beetle

- Scenic beauty

- Not overgrown with bushes or grass

Fig. 5. Koyukon respondent positive and negative comments about wildfire effects. Note that the numbers on the $\mathrm{X}$-axis refer to the number of respondents who provided each response.

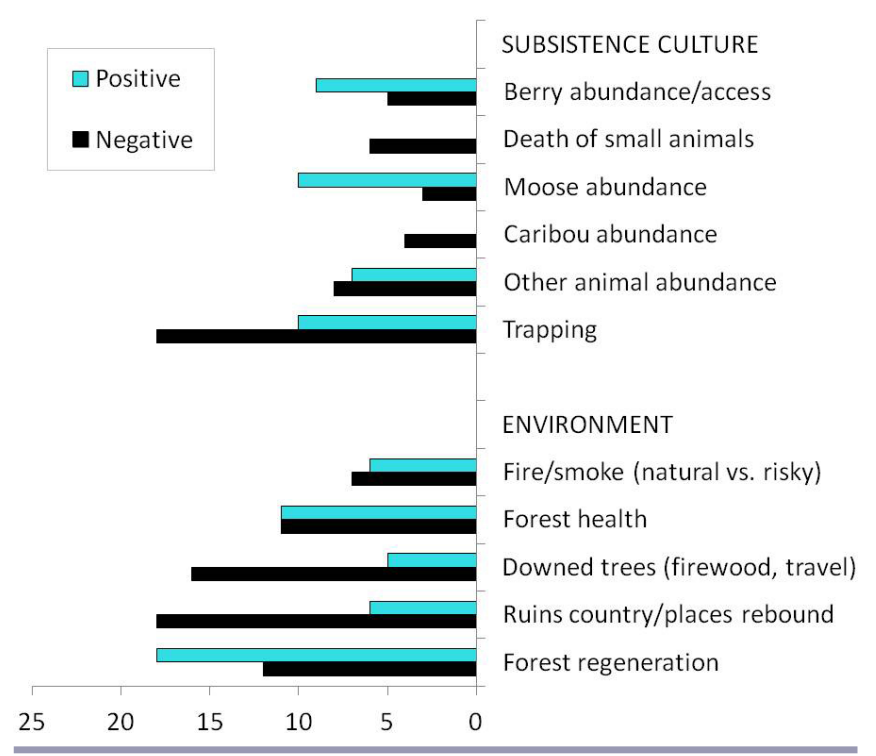


Fig. 6. Fire effects as reported by Koyukon respondents. First column represents type of burn, second column represents primary effects, third column represents secondary effects, and fourth column represents tertiary effects. Note that the numbers in parentheses refer to the number of respondents who provided that response.

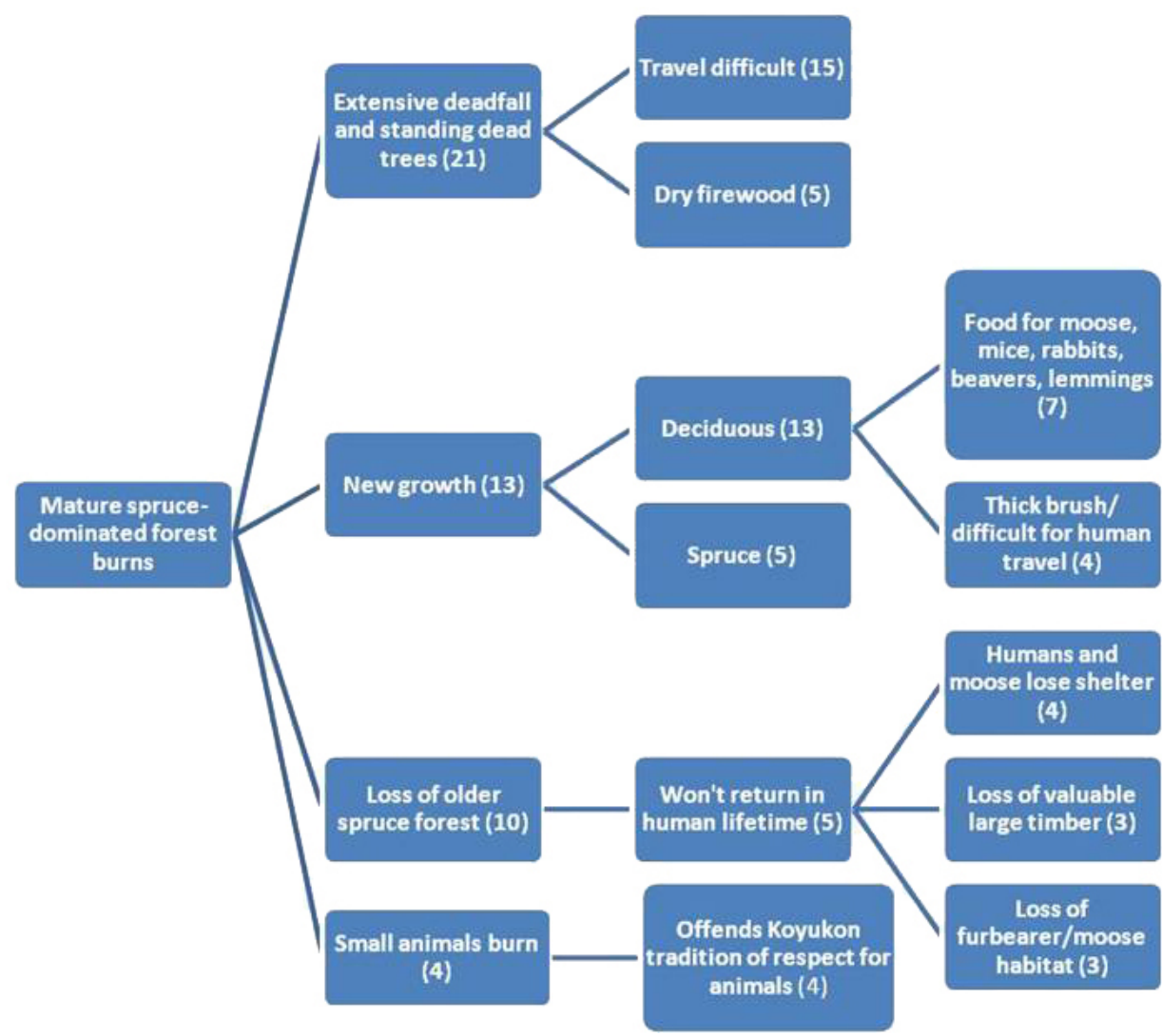

travel, the loss of important places, difficulties trapping, caribou displacement, and the deaths of small animals. Although some comments seemed contradictory, multiple respondents explained that wildfire effects varied dramatically by vegetation type and environmental conditions during the burn. Respondents with distinct traditional use areas observed different wildfire effects. Participants described wildfire effects on mature, spruce-dominated forest areas (Figure 6), non-spruce features (Figure 7), and soil and organic mats (Figure 8) as both environmental and subsistence use changes. Some respondents indicated that mild to moderate wildfires were more likely to have beneficial or neutral effects on subsistence, and severe wildfires were more likely to complicate subsistence uses (Figure 2). Many of the effects reported for the burning of soil, organic mats, and mature spruce-dominated forest areas were the negative effects associated with severe wildfires (Figure 5).

\section{Resource management agency perspective}

Drivers of landscape flammability

General

The FMP focused on the three legs of the fire behavior triangle (Countryman 1972), and the associated conditions for each leg influencing fire danger and fire behavior (Figure 9).

Changes in landscape and climate

The FMP did not address climate change, simply commenting that:

Fire is an integral part of the ecosystem and has caused plants and animals to adapt to fire over the eons. Climate change, especially in the interior, may alter some of these fire relationships. (Alaska Region U.S. Fish and Wildlife Service 2005:3) 
Fig. 7. Fire effects as reported by Koyukon respondents. First column represents general type of burn, second column represents specific type of burn, and third column represents effects of burning. Note that the numbers in parentheses refer to the number of respondents who provided that response.

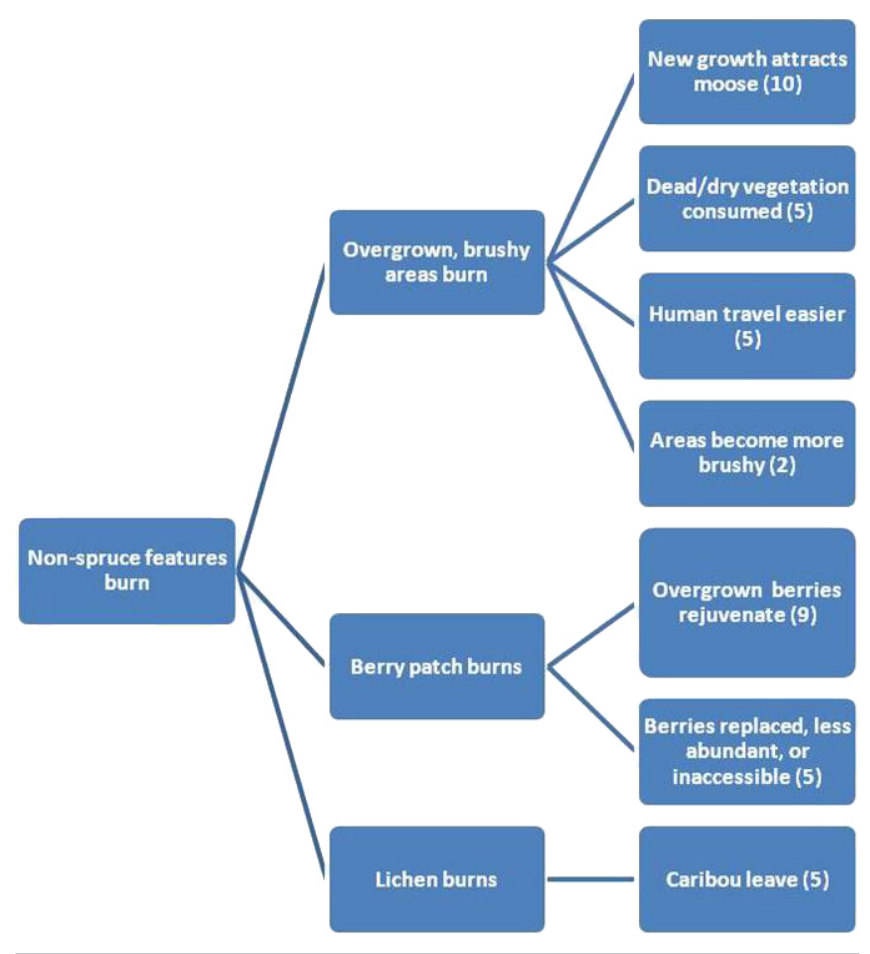

Additionally, the FMP did not mention any trend of vegetation overgrowth, but described vegetation as within the natural range of variability while noting that wildfire suppression could cause a shortage of early successional vegetation.

Time since wildfire

The FMP classified the Koyukuk and Northern Unit Innoko refuges as naturally supporting infrequent (35-100+ years) mixed to high severity wildfires, and related flammability more to weather, fuels, and topography than to time since wildfire. The FMP also described the Koyukuk Refuge as within the "natural range of variability" (Alaska Region U.S. Fish and Wildlife Service 2005:25) for vegetation and fuel characteristics and fire frequency and severity, but expressed concern that fire suppression could shift fire regimes away from historical conditions without specifically defining how that shift in fire regimes would manifest itself in fire behavior and effects. Additionally, the FMP recommended wildland and prescribed fire use to restore fire-adapted ecosystems, reduce "hazardous fuel accumulations", and "lower the risk of catastrophic fire" (Alaska Region U.S. Fish and Wildlife
Service 2005:26), thus implying some relationship between flammability and time since burn.

\section{Fire as a management tool}

The FMP was analyzed for resource management objectives, including those met by fire (Table 2). The FMP predicted multiple beneficial resource effects from wildfires and prescribed fires (Figure 10) but did not support predictions with observational data or published citations. Overall, the FMP did not describe much variability in wildfire effects or clearly connect wildfire severity to effects on resources (Figure 10). Although the FMP primarily related severity to fire suppression decisions, it did note that (1) prescribed burns must meet certain environmental conditions to achieve desired objectives, (2) research is needed to see whether wildland and prescribed fires are meeting resource management objectives, (3) very high fire intensities (defined in the FMP as an estimate of heat per unit length of fire edge per unit time) can cause unwanted plant mortality, and (4) fires that smolder too long can destroy root systems.

Fig. 8. Fire effects as reported by Koyukon respondents. First column represents type of burn, second column represents primary effects, and third column represents secondary effects. Note that the numbers in parentheses refer to the number of respondents who provided that response.

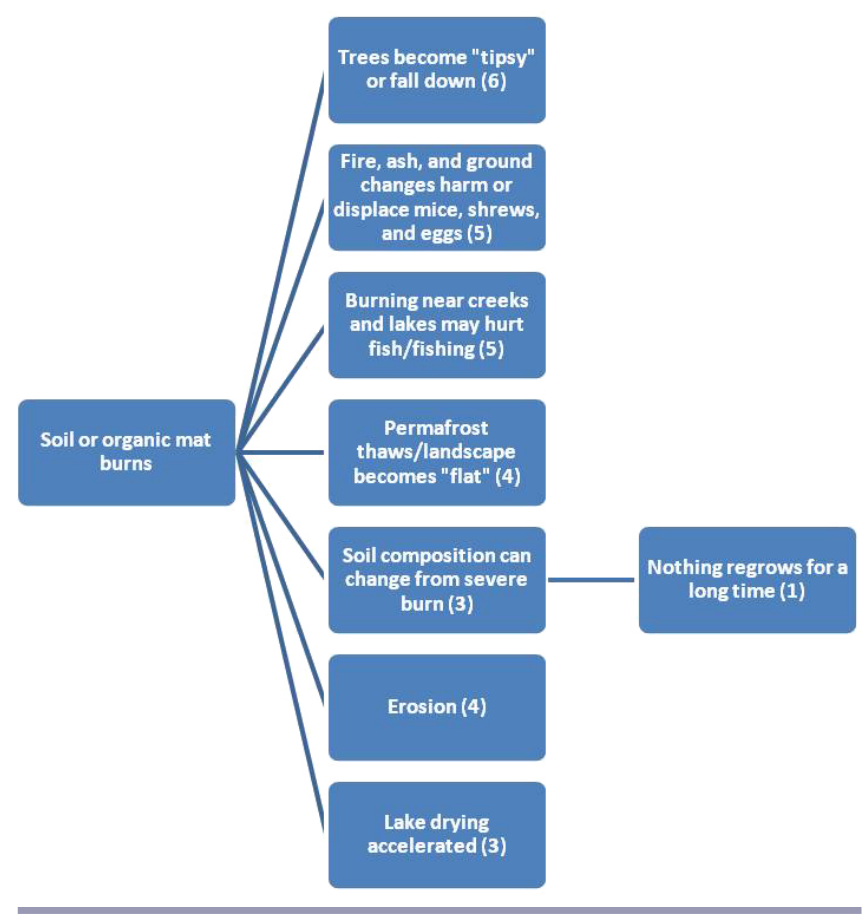


Fig. 9. Factors affecting wildfire behavior as related by Koyukuk National Wildlife Refuge Fire Management Plan (FMP).

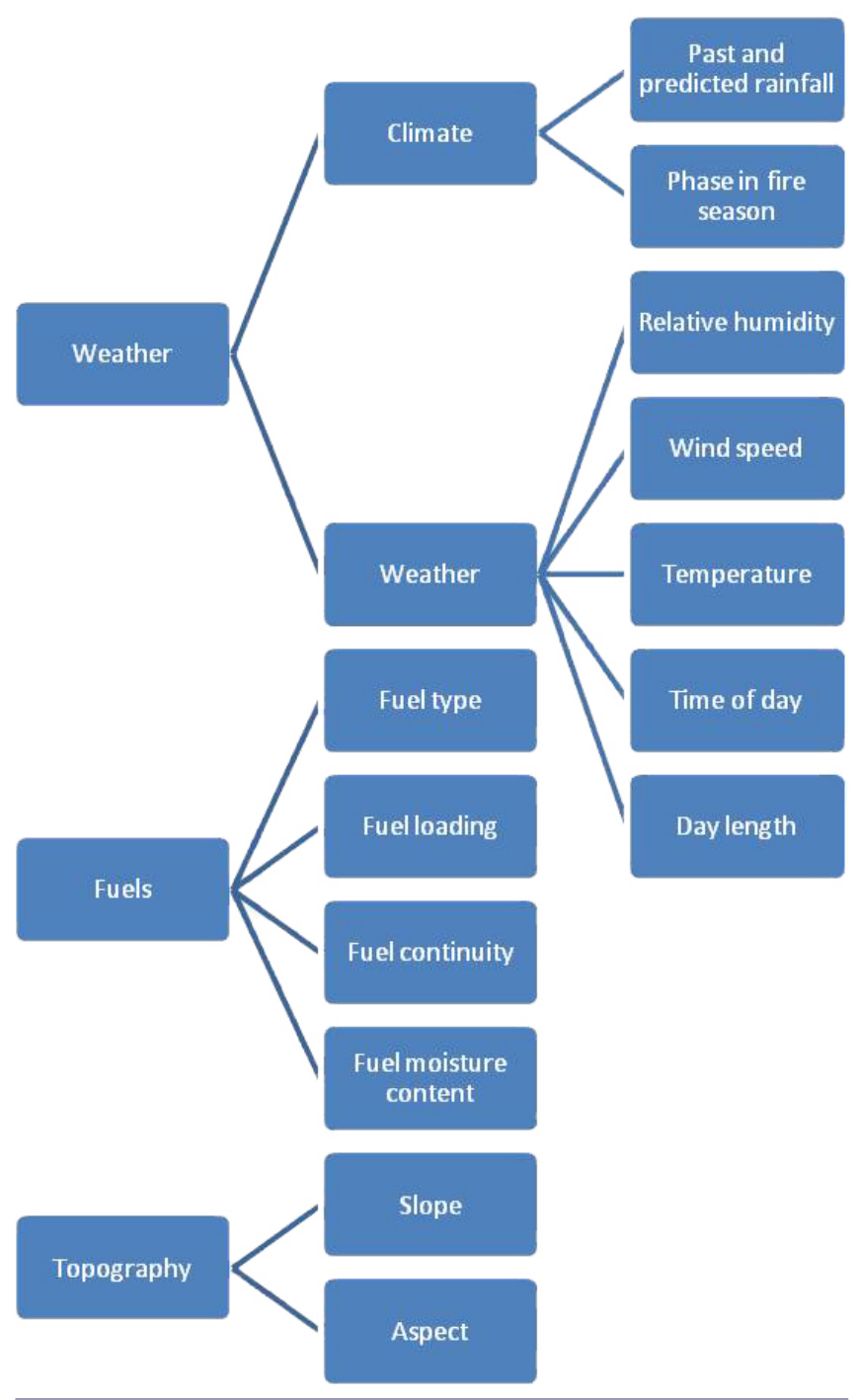

\section{DISCUSSION}

\section{Drivers of flammability}

The two sources of information (TEK and the FMP) identify the same general drivers of flammability (Table 3 ). Since these general drivers (topography, fuels, and weather) comprise the three legs of the fire environment triangle globally (Countryman 1972), the FMP follows a national narrative and regional science that TEK confirms locally.

Analysis of climate change recognition indicates that reliance on national narratives at the expense of regional science can drive community/agency conflict (Table 3). Many older Koyukon residents perceived an increase in landscape
Table 2. Objectives listed in the Koyukuk National Wildlife Refuge Fire Management Plan (FMP).

\begin{tabular}{ll}
\hline \hline Objective & Number \\
& of times \\
mentione & in FMP \\
\end{tabular}

†Use fire as a natural ecological process/maintain fire-

26

dependent ecosystems

$\dagger$ Avoid catastrophic fires/reduce fuel load

$\dagger$ Improve habitat/maintain wildlife populations

$\dagger$ Maintain early successional habitats

$\nmid$ Restore fire-adapted ecosystems/historic conditions

$\dagger$ Conduct research on effects of wildland and prescribed fire

Protect cultural/historic/archeological sites

$\dagger$ Maintain wilderness values

$\dagger$ Provide willow regrowth for moose habitat

$\dagger$ Use wildland and prescribed fire for resource management objectives

Preserve subsistence access

$\dagger$ Protect wetlands for waterfowl or muskrat

Protect sensitive habitat (peregrine falcon or caribou)

$\dagger$ Maintain diverse vegetative mosaic

Maintain recreational opportunities

Protect water quality

Protect community values

$\dagger$ fire described as a method to meet the management objective.

flammability due to warmer summers and winters and a drying landscape that was more prone to overgrowth. Considerable regional science supports these observations, as recent research indicates a reduction in surface water, boreal forest browning, increasing wildfire activity and consumption of the organic layer, larger areas burning, later season burning, and shifting forest composition (Chapin et al. 2006, Kasischke and Turetsky 2006, Riordan et. al. 2006, Johnstone et al. 2010, Kasischke et al. 2010, Verbyla 2011, Wolken et al. 2011). In contrast to nearly two decades of regional and national science highlighting climatically-induced changes in wildfire regimes, U.S. wildfire policy did not recognize the effects of climate change until the 2009 passage of the FLAME Act $(\mathrm{H}$. R. 2996), a lag in recognition evident not only in the FMP, but nationally in the U.S. fire management system (Kolden and Brown 2010).

Finally, community/agency perspectives on the relationship between flammability and time since burn indicated neither conflict nor agreement between a national narrative and TEK (Table 3). The FMP identifies the natural fire return interval at 35-100 years and implies that overzealous fire suppression has unnaturally delayed fire occurrence in fire-adapted forests, producing "hazardous" fuel accumulation conducive to catastrophic wildfires, paralleling the national narrative. 
Fig. 10. Description of factors driving wildfire severity and resultant effects on resources in the Koyukuk National Wildlife Refuge Fire Management Plan (FMP).

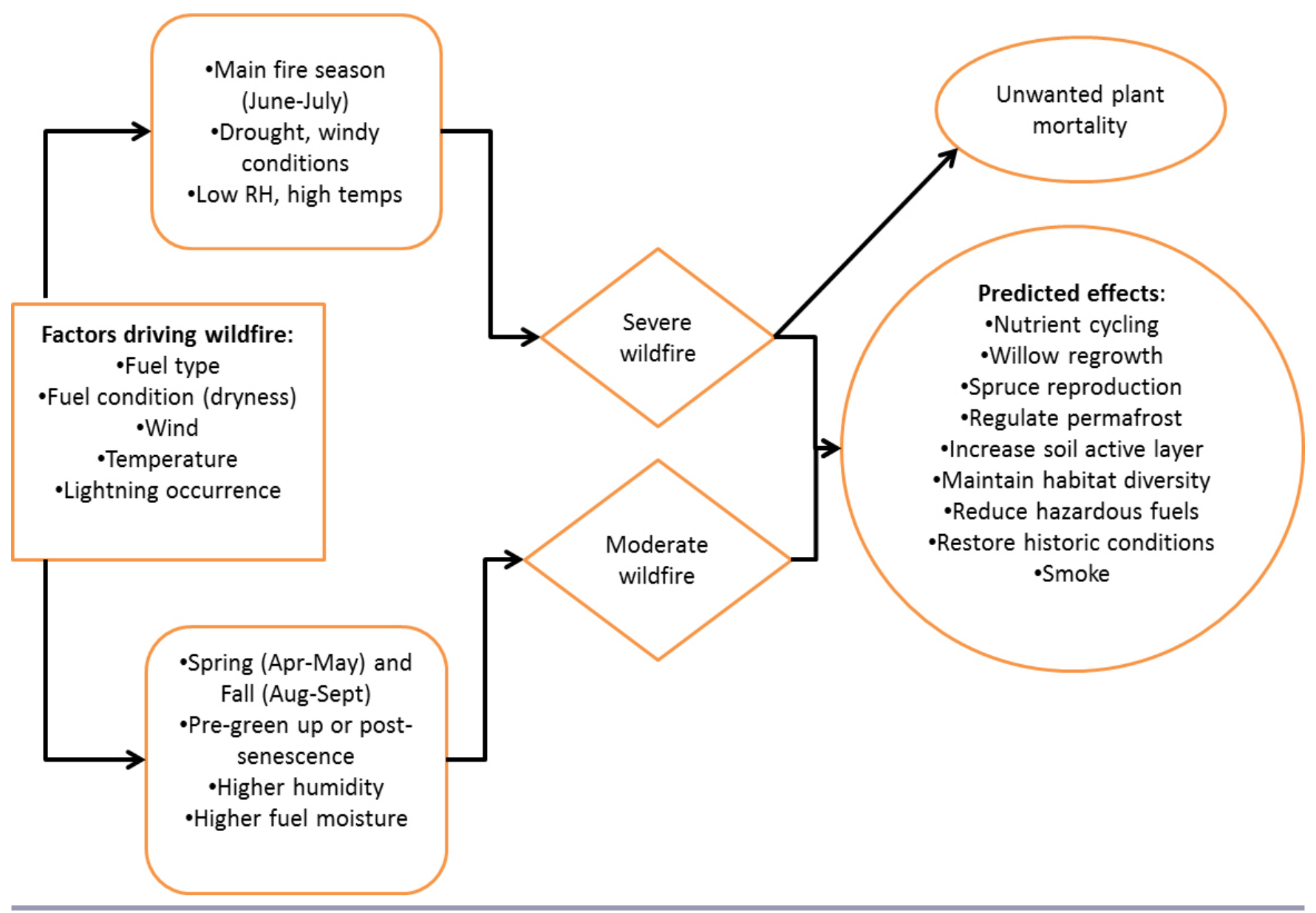

Regional science, however, indicates that a late successional, fire-adapted spruce forest capable of carrying a high severity wildfire develops over decades to multiple centuries, and flammability is linked to fuel type and climatic conditions, not an overaccumulation of "hazardous fuels" (Johnson et al. 2001, Chapin et al. 2006). Furthermore, the fire cycle in the Yukon River lowlands region is estimated at 171-230 years (Kasischke et al. 2002), far exceeding the human lifespan. Koyukon respondents had varying views on flammability, with some indicating flammability increased with time since burn, others stating that wildfires increased flammability, and the majority describing flammability through factors not directly related to the wildfire regime. Those respondents describing places that became more flammable over time primarily referred to brushy areas and not to spruce forests. A recent study indicates that climate change has increased the proportion of mid-succession shrublands burning in Alaska's boreal forest, particularly during record warm years in the 2000s (Kolden 2010).
Fire as a management tool

Substantial community/agency conflict emerged over the idea of wildfire as a management tool (Table 4). In general, community respondents perceived highly variable wildfire effects, with the negative outweighing the positive (Figure 5), whereas the FMP lauded wildfire's role as a natural process and its theoretical potential to reduce hazardous fuels and improve habitat (Tables 2 and 4). This conflict had two major origins: (1) different resource management objectives between the two groups, and (2) conflicting agency approaches dominated by national narratives at the expense of regional science or local observations.

While numerous regional studies have reported widely variable fire effects similar to those observed by Koyukon respondents (Viereck 1983, Chapin et al. 2006, Johnstone and Chapin 2006, Shenoy et al. 2011), the FMP failed to acknowledge this variability and highlighted only the potentially desirable effects. Furthermore, the FMP first stated that fires have burned naturally on the Refuge within their 
Table 3. Drivers of flammability.

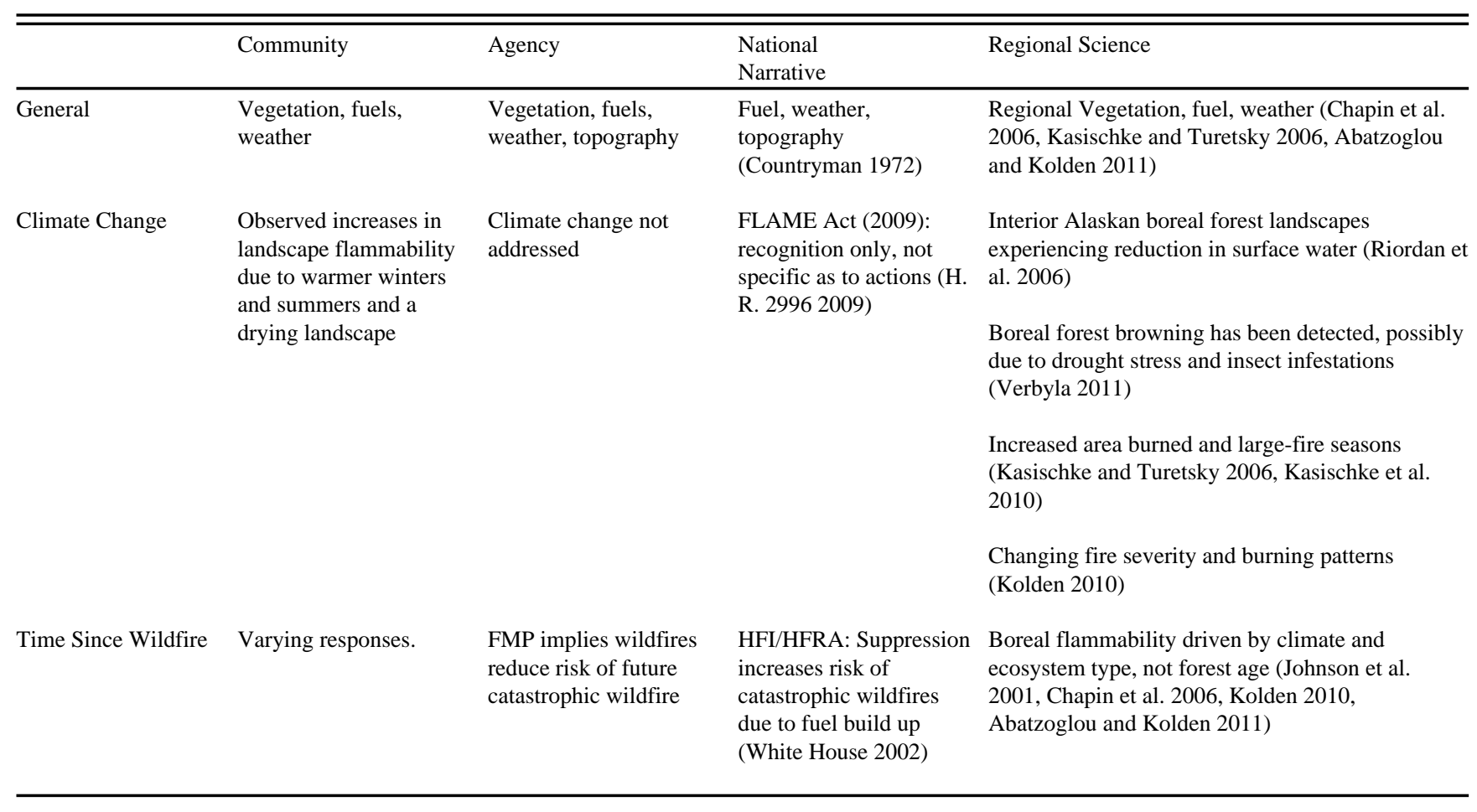

historic range of variability, but then suggested that wildland and prescribed fires are necessary for resource benefits, to reduce hazardous fuels, and to return fire regimes to their historic conditions. This management approach is supported by neither regional science nor the FMP itself and likely stems from the HFI/HFRA requiring projects to include "hazardous fuels" reduction in order to receive national funding (Steelman and Burke 2007, Kolden and Brown 2010). This emphasis on adding additional fire to an ecosystem that has never seen fully effective suppression and, additionally, has experienced climatically induced increases in fire activity, is perhaps the most transparent displacement of TEK and regional science by a national fire policy narrative.

\section{TEK and Regional Science}

Although many local observations corresponded with regional science, there are advantages to incorporating both into management. First, as demonstrated by the figures, local observations can add fine-scale local details and historical context, detect changes yet undocumented in scientific studies, and indicate which regional studies apply to a given locale. Additionally, incorporating rural users into resource management is ethical, as management directly affects local well-being, and practical, as it can reduce conflict over resource management (Western and Wright 1994). Incorporation of local knowledge about local variability in fire effects can facilitate the development of fire management strategies that maximize benefits and minimize the negative effects of wildfire through landscape-scale management. Finally, given federal mandates for government-togovernment relationships with tribes (White House 1994), and the mandate of the Alaska National Interest Lands Conservation Act (ANILCA) to prioritize subsistence uses on federal lands (Public Law 96-87 1980), there is considerable legal precedent for including indigenous knowledge and values in wildfire management.

\section{Limitations of this research}

As respondents were allowed considerable control over interview direction, the topics discussed varied and some valuable observations were noted by only a few respondents. While research has shown that TEK is not evenly distributed and that the best observations will come from the most knowledgeable informants about a specific topic and not from the largest number of informants (Chalmers and Fabricius 2007), it would have been useful to determine which of the less common observations were more broadly shared, perhaps through a survey. The uneven distribution of observations does suggest that there is value in working with a large number of respondents when doing qualitative environmental research, as no one respondent will have observations as topically, temporally, and spatially diverse as a larger group.

Interview design influenced the disparity in reported observations of change, as the interviews specifically asked respondents to describe changes they had seen in subsistence 
Table 4. Feasibility of using fire to meet resource management objectives.

\begin{tabular}{|c|c|c|c|c|}
\hline & Community & Agency & National & Regional Science \\
\hline $\begin{array}{l}\text { Resource } \\
\text { Management } \\
\text { Objectives }\end{array}$ & $\begin{array}{l}\text { Protect subsistence, } \\
\text { including diversity } \\
\text { of plants, animals, } \\
\text { and ecosystem } \\
\text { functions }\end{array}$ & $\begin{array}{l}\text { 1) Use fires as a } \\
\text { natural ecological } \\
\text { process/maintain fire- } \\
\text { dependent } \\
\text { ecosystems } \\
\text { 2)Reduce hazardous } \\
\text { fuels/ avoid } \\
\text { catastrophic fires } \\
\text { 3) Improve habitat }\end{array}$ & $\begin{array}{l}\text { 1) Maintain the natural role of } \\
\text { fire as an essential process in } \\
\text { fire-adapted ecosystems } \\
\text { 2) Reduce hazardous fuels to } \\
\text { lower risk of catastrophic fire } \\
\text { to communities and critical } \\
\text { resources } \\
\text { (Department of the Interior } \\
\text { 1995, 2001, White House } \\
\text { 2002) }\end{array}$ & $\begin{array}{l}\text { Increase ecosystem resilience/address ecosystem } \\
\text { vulnerability to climate change (Chapin et al. 2003, } \\
\text { Trainor et al. 2009) } \\
\text { Continue with variable fire-suppression policy that } \\
\text { protects communities while supporting natural fire } \\
\text { regime (DeWilde and Chapin 2006) }\end{array}$ \\
\hline $\begin{array}{l}\text { Feasibility of } \\
\text { Using Wildfire to } \\
\text { Meet Resource } \\
\text { Management } \\
\text { Objectives }\end{array}$ & $\begin{array}{l}\text { High severity fire } \\
\text { has many negative } \\
\text { consequences, } \\
\text { moderate severity } \\
\text { fire has some } \\
\text { benefits, but fire } \\
\text { effects are largely } \\
\text { unpredictable }\end{array}$ & $\begin{array}{l}\text { Optimistic prediction } \\
\text { of multiple resource } \\
\text { benefits, no } \\
\text { recognition of } \\
\text { negative } \\
\text { consequences of fire }\end{array}$ & $\begin{array}{l}\text { Prescribed fire and wildland } \\
\text { fire use are the most cost- } \\
\text { effective and natural methods } \\
\text { to returning fire to fire-adapted } \\
\text { ecosystems and maintaining } \\
\text { ecological resilience } \\
\text { (Department of the Interior } \\
\text { 1995, 2001, Arno and Allison- } \\
\text { Bunnell 2002, Stephens and } \\
\text { Ruth 2005) }\end{array}$ & $\begin{array}{l}\text { Regional Fire has not been removed from Alaskan } \\
\text { ecosystems by suppression (Kasischke et al. 2002) } \\
\text { Reduced insect species diversity } 10 \text { years after } \\
\text { prescribed fire (Werner 2002) } \\
\text { Wildfires can have negative or unpredictable effects on } \\
\text { certain species (Hood et al. 2007, Nelson et al. 2008) } \\
\text { Burns have long-term harmful effects on caribou, studies } \\
\text { on furbearers and their prey have shown mixed results } \\
\text { (Pearce and Venier 2005, Rupp et al. 2006, Nelson et al. } \\
\text { 2008). }\end{array}$ \\
\hline
\end{tabular}

areas over their lifetimes, and the FMP template did not require mangers to document changes in area landscapes or wildfire regimes. We contend, that, rather than indicating a flaw in the study, this indicates a gap in FMP design, as sustainable wildfire management policy must consider the dramatic observed and predicted changes in Alaska's wildfire regime.

Previous research has shown that wildland firefighting is an important source of income for many rural village residents (Trainor 2006), which may influence some communities' wildfire policy preferences. As we documented direct observations of wildfire effects on the landscape, rather than wildfire policy preferences, we consider this influence to be minimal. Additionally, research in Galena and Huslia indicated that younger residents, of firefighting age, had more positive views of wildfires than the older residents who could no longer firefight (Ray 2011), indicating that firefighting income was not the primary driver of negative views on wildfires.

\section{CONCLUSION}

The study results indicated that some disagreements between traditional ecological knowledge and resource management policies can result from conformance of management to national narratives despite contrary evidence from regional science and traditional ecological knowledge. In this case, climate change effects on the boreal wildfire regime were well documented by both indigenous residents and regional scientists but were overlooked in federal resource management policies that ignored climate change and focused on hazardous fuels accumulation. Additionally, the FMP neglected regional research and local observations on the variability of wildfire effects. Comparing TEK with existing regional science indicated that, despite the FMP proclamation that "it will take some time to educate the local public of the ecological benefits of wildland and prescribed fire," (Alaska Region U.S. Fish and Wildlife Service 2005:5) the local forest users, as a group, have important observations of the range of possible wildfire effects that are not documented in the FMP and are generally consistent with regional science.

Federal fire management must play a delicate balancing act in answering to national policy mandates, synthesizing the best available local or regional science, and addressing impacts to local stakeholders. When local and regional science is limited and/or displaced by a national narrative, TEK can provide information that enables regional fire managers to challenge the national narrative and to work with communities to coproduce a locally appropriate management strategy. TEK is particularly valuable in places like Alaska, where TEK is relatively rich, refuge-based science is limited by the recent establishment of refuges and their constrained funding for research, and management actions have potentially large impacts on livelihoods in small indigenous communities such as Galena and Huslia. Indigenous communities retain federally protected rights to subsistence, the customary and traditional 
uses of wild resources, on federal lands, and integrating TEK may help federal wildfire management meet this obligation to indigenous tribes.

We suggest that fire managers in Alaska and elsewhere look to the model provided by community-based natural resource management, which recognizes the right of resourcedependent communities to participate in environmental decision making and embraces community knowledge and local resource management traditions (Brosius et al. 2005). Additionally, we propose that disagreements between TEK and resource management policies do not prevent collaboration, but rather indicate places where national narratives may not fit local environments, making traditional ecological knowledge and regional science essential to sustainable management. We recommend that future fire management plans incorporate both community observations and the best available regional science, especially on climate change and the variability of wildfire effects. Furthermore, we suggest that national fire narratives advocating the blanket use of prescribed fire are just as harmful in some fire regimes as previous full suppression policies were to southwestern pine forests. National fire policy makers would do well to recognize the spatial variability of fire regimes and the importance of incorporating place-based TEK and regional science into local fire management policies.

Responses to this article can be read online at: http://www.ecologyandsociety.org/vol17/iss3/art37/ responses/

\section{Acknowledgments:}

The first author would like to thank Billie Turner for support throughout the research process, the residents of Galena and Huslia for their participation in this study, and Bob Lambrecht, Dianne Rocheleau, John Rogan, and Jody Emel for support early in the research process. The research was supported in part by the National Science Foundation (Graduate Research Fellowship Program and Grants 0620579, 0654441, and 0732758 to the University of Alaska, Fairbanks as part of the Bonanza Creek Long-Term Ecological Research program, the Resilience and Adaptation Program, and the Ecosystem Services Project of the International Polar Year) and the Community Forestry Research Fellowship Program. The U. S. Fish and Wildlife Service, Koyukuk National Wildlife Refuge, provided extensive logistical support in the field. Any opinions, findings, conclusions, or recommendations expressed in this publication are those of the authors and do not necessarily reflect the views of the National Science Foundation, the U.S. Fish and Wildlife Service, or the Community Forestry Research Fellowship Program.

\section{LITERATURE CITED}

Abatzoglou, J. T., and C. A. Kolden. 2011. Relative importance of weather and climate on wildfire growth in interior Alaska. International Journal of Wildland Fire 20 (4):479-486.

Acheson, J. M., J. A. Wilson, and R. S. Steneck. 1998. Managing chaotic fisheries. Pages 390-413 in F. Berkes, and C. Folke, editors. Linking social and ecological systems: management practices and social mechanisms for building resilience. Cambridge University Press, New York, New York, USA.

Alaska Region U.S. Fish and Wildlife Service. 2005. Koyukuk and Northern Unit Innoko National Wildlife Refuge wildfire management plan. U.S. Fish and Wildlife Service, Galena, Alaska, USA.

Alexander, C., N. Bynum, E. Johnson, U. King, T. Mustonen, P. Neofotis, N. Oettle, C. Rosenzweig, C. Sakakibara, V. Shadrin, M. Vicarellu, J. Waterhouse, and B. Weeks. 2011. Linking indigenous and scientific knowledge of climate change. Bioscience 61(6):477-484.

Anderson, M. K. 2005. Tending the wild: Native American knowledge and the management of California's natural resources. University of California Press, Berkeley, California, USA.

Arno, S., and S. Allison-Bunnell. 2002. Flames in our forest: disaster or renewal? Island Press, Covelo, California, USA.

Auerback, C. F. and L. B. Silverstein. 2003. Qualitative data. New York University Press, New York, New York, USA.

Berkes, F. 1987. Common-property resource management and Cree Indian fisheries in subarctic Canada. Pages 66-91 in B. M. McCay, and J. M. Acheson, editors. The question of the commons. University of Arizona Press, Tucson, Arizona, USA.

Berkes, F. 2007. Community-based conservation in a globalized world. Proceedings of the National Academy of Sciences 104(39):15188-15193. http://dx.doi.org/10.1073/pna s.0702098104

Berkes, F. 2008. Sacred ecology: traditional ecological knowledge and resource management. 2nd edition. Taylor \& Francis, Philadelphia, USA.

Berkes, F., J. Colding, and C. Folke. 2000. Rediscovery of traditional ecological knowledge as adaptive management. Ecological Applications. 10(5):1251-1262.

Berkes, F., and C. Folke. 1998. Linking social and ecological systems for resilience and sustainability. Pages 1-25 in F. Berkes, and C. Folke, editors. Linking social and ecological systems: management practices and social mechanisms for building resilience. Cambridge University Press, New York, New York, USA. 
Bernard, H. R. 2006. Research methods in anthropology. Altamira Press, Lanham, Maryland, USA.

Brosius, J. P., A. L. Tsing, and C. Zerner, editors. 2005. Communities and conservation. Altamira, Walnut Creek, California, USA.

Brown, P., J. Agee, and J. Franklin. 2004. Forest restoration and fire: principles in the context of place. Conservation Biology 18(4):903-912. http://dx.doi.org/10.1111/j.1523-173 9.2004.521_1.x

Carroll, M. S., P. J. Cohn, T. B. Paveglio, D. R. Drader, and P. J. Jakes. 2010. Fire burners to firefighters: the Nez Perce and fire. Journal of Forestry 108(2):71-76.

Chalmers, N., and C. Fabricius. 2007. Expert and generalist local knowledge about land-cover change on South Africa's Wild Coast: can local ecological knowledge add value to science? Ecology and Society12(1):10. [online] URL: http:// www.ecologyandsociety.org/vol12/iss1/art10/

Chapin, F. S., III, M. W. Oswood, K. Van Cleve, L. A. Viereck, and D. L Verbyla, editors. 2006. Alaska's changing boreal forest. Oxford University Press, New York, New York, USA.

Chapin, F. S., T. S. Rupp, A. M. Starfield, L. DeWilde, E. S. Zavaleta, N. Fresco, J. Henkelman, and A. D. McGuire. 2003. Planning for resilience: modeling change in human-fire interactions in the Alaskan boreal forest. Frontiers in Ecology and the Environment 1(5):255-261. http://dx.doi.org/10.1890 11540-9295(2003)001[0255:PFRMCI]2.0.CO;2

Chapin, F. S., III, S. F. Trainor, O. Huntington, A. L. Lovecraft, E. Zavaleta, D. C. Natcher, A. D. McGuire, J. L. Nelson, L. Ray, M. Calef, N. Fresco, H. Huntington, R. T. Scott, L. DeWilde, and R. L. Naylor. 2008. Increasing wildfire in the boreal forest: causes, consequences, and pathways to potential solutions of a wicked problem. Bioscience 58(6):531-540. http://dx.doi.org/10.1641/B580609

Countryman, C. M. 1972. The fire environment concept. U.S. Department of Agriculture, Forest Service, Pacific Southwest Range and Experiment Station, Berkeley, California, USA.

Cruikshank, J. 2000. The social life of stories. Bison, Omaha, Nebraska, USA.

Department of the Interior. 1995. Federal wildland fire management policy and program review. [online] URL: http: //www.nwcg.gov/branches/ppm/fpc/archives/fire_policy/ mission/1995 fed wildland fire policy program report.pdf

Department of the Interior. 2001. Update of the 1995 federal wildland fire management policy and program review. [online] URL: http://www.nwcg.gov/branches/ppm/fpc/archives/fire policy/ history/index.htm
Department of the Interior. 2009. Interagency fire management plan template. [online] URL: http://www.nwcg. gov/branches/ppm/ifpc/fmp/ifmp-template.pdf. Last accessed February 20, 2012.

DeWilde, L., and F. S. Chapin, III. 2006. Human impacts on the fire regime of interior Alaska: interactions among fuels, ignition sources, and fire suppression. Ecosystems 9 (8):1342-1353. http://dx.doi.org/10.1007/s10021-006-0095-0

Fernandez-Gimenez, M. E, H. P. Huntington, and K. J. Frost. 2006. Integration or co-optation? Traditional knowledge and science in the Alaska Beluga Whale Committee. Environmental Conservation 33(4):306-315. http://dx.doi.org /10.1017/S0376892906003420

Gilchrist, G., M. Mallory, and F. Merkel. 2005. Can local ecological knowledge contribute to wildlife management? Case studies of migratory birds. Ecology and Society. 10(1):20 [online] URL: www.ecologyandsociety.org/vol10/iss1/art20/

Glaser, B. G., and A. L. Strauss. 1967. The discovery of grounded theory: strategies for qualitative research. Aldine Transaction, New Brunswick, New Jersey, USA. http://dx.doi. org/10.1097/00006199-196807000-00014

Holling, C. S. 1978. Adaptive environmental assessment and management. John Wiley and Sons, New York, New York, USA.

Holling, C. S., F. Berkes, and C. Folke. 1998. Science, sustainability, and resource management. Pages 342-362 in F. Berkes, and C. Folke, editors. Linking social and ecological systems: management practices and social mechanisms for building resilience. Cambridge University Press, New York, New York, USA.

Hood, G. A., S. E. Bayley, and W. Olso. 2007. Effects of prescribed fire on habitat of beaver (Castor canadensis) in Elk Island National Park, Canada. Forest Ecology and Management 239(103):200-209. http://dx.doi.org/10.1016/j.f oreco.2006.12.005

H.R. 2996. 111th Congress: Department of the Interior, Environment, and Related Agencies Appropriations Act, 2010. 2009. [online] URL: http://www.govtrack.us/congress/ bill.xpd?bill=h111-2996

Huntington, H. P. 1998. Observations on the utility of the semidirective interview for documenting traditional ecological knowledge. Arctic 51(3)237-242.

Huntington, H. P. 2000. Using traditional ecological knowledge in science: methods and applications. Ecological Applications 10(5):1270-1274. http://dx.doi.org/10.1890/105 1-0761(2000)010[1270:UTEKIS]2.0.CO;2 
Huntington, H. P., S. F. Trainor, D. C. Natcher, O. H. Huntington, L. DeWilde, and F. Stuart Chapin III. 2006. The significance of context in community-based research: understanding discussions about wildfire in Huslia, Alaska. Ecology and Society 11(1):40. [online] URL: www.ecologya ndsociety.org/vol11/iss1/art40/

Johnson, E. A., K. Miyanashi, and S. R. J. Bridge. 2001. Wildfire regime in the boreal forest and the idea of suppression and fuel buildup. Conservation Biology 15(6):1554-1557. http://dx.doi.org/10.1046/j.1523-1739.2001.01005.x

Johnstone, J., and F. S. Chapin, III. 2006. Effects of soil burn severity on post-fire tree recruitment in boreal forest. Ecosystems 9(1):14-31. http://dx.doi.org/10.1007/s10021-004 $\underline{-0042-\mathrm{x}}$

Johnstone, J. F., F. S. Chapin, III, T. N. Hollingsworth, M. C. Mack, V. Romanovsky, and M. Turetsky. 2010. Fire, climate change, and forest resilience in interior Alaska. Canadian Journal of Forest Research 40:1302-1312. http://dx.doi.org/1 $\underline{0.1139 / X 10-061}$

Johnstone, J. F., T. N. Hollingsworth, F. S. Chapin, III, and M. C. Mack. 2010. Changes in fire regime break the legacy lock on successional trajectories in Alaskan boreal forest. Global Change Biology 16(4):1281-1295. http://dx.doi.org/1 0.1111/j.1365-2486.2009.02051.x

Kane, E. S., E. S. Kasischke, D. W. Valentine, M. R. Turetsky, and A. D. McGuire. 2007. Topographic influences on wildfire consumption of soil organic carbon in interior Alaska: implications for black carbon accumulation. Journal of Geophysical Research-Atmospheres 112:G03017. http://dx. doi.org/10.1029/2007JG000458

Kasischke, E. S., and M. R. Turetsky. 2006. Recent changes in the fire regime across the North American boreal region: spatial and temporal patterns of burning across Canada and Alaska. Geophysical Research Letters 33, LO9703. http://dx. doi.org/10.1029/2006GL025677

Kasischke, E. S., D. L. Verbyla, T. S. Rupp, A. D. McGuire, K. A. Murphy, R. Jandt, J. L. Barnes, E. E. Hoy, P. A. Duffy, M. Calef, and M. R. Turetsky. 2010. Alaska's changing fire regime- implications for the vulnerability of its boreal forests. Canadian Journal of Forest Research 40(7):1313-1324. http: //dx.doi.org/10.1139/X10-098

Kasischke, E. S., D. Williams, and D. Barry. 2002. Analysis of the patterns of large fires in the boreal forest region of Alaska. International Journal of Wildland Fire 11(2):131-144. http://dx.doi.org/10.1071/WF02023

Kates, R. W., W. C. Clark, R. Corell, J. M. Hall, C. C. Jaeger, I. Lower, J. J. McCarthy, H. J. Schellnbuber, B. Bolin, N. M. Dickson, S. Faucheuz, G. C. Gallopin, A. Grubler, B. Huntley, J. Jager, N. S. Jodha, R. E. Kasperson, A. Mabogunje, P. A.
Matson, and H. Mooney. 2001. Sustainability science. Science 292(5517):641-642. http://dx.doi.org/10.2139/ssrn.257359

Kofinas, G., Aklavik, Arctic Village, Old Crow, and F. McPherson. 2002. Community contributions to ecological monitoring: knowledge co-production in the U.S.- Canada Arctic borderlands. Pages 54-91 in I. Krupnik, and D. Jolly, editors. The earth is faster now: indigenous observations of Arctic environmental change. Arctic Reseach Consortium of the United States, Fairbanks, Alaska, USA.

Kolden, C. A. 2010. Characterizing Alaskan wildfire regimes through remotely sensed data: assessments of large area pattern and trend. Dissertation. Clark University, Worcester, Massachusetts, USA.

Kolden, C. A., and T. J. Brown. 2010. Beyond wildfire: perspectives of climate, managed fire and policy in the USA. International Journal of Wildland Fire 19(3):364-373. http:// dx.doi.org/10.1071/WF08111

Krupnik, I., and D. Jolly, editors. 2002. The earth is faster now: indigenous observation of Arctic environmental change. Arctic Research Consortium of the United States, Fairbanks, Alaska, USA.

Lake, F. K. 2007. Traditional ecological knowledge to develop and maintain fire regimes in northwestern California, Klamath-Siskiyou bioregion: management and restoration of culturally significant habitats. Dissertation. Oregon State University, Corvallis, Oregon, USA.

Lewis, H. T., 1989. Ecological and technological knowledge of fire: Aborigines versus park rangers in northern Australia. American Anthropologist 91:940-961. http://dx.doi.org/10.1525/ aa.1989.91.4.02a00080

Machlis, G., A. Kaplan, S. Tuler, K. Bagby, and J. McKendry. 2002. Burning questions: a social science research plan for federal wildland fire management. University of Idaho, Moscow, Idaho, USA.

Marcotte, J. 1986. Contemporary resource use patterns in Huslia, Alaska, 1983. Technical Paper 133. Alaska Department of Fish and Game, Division of Subsistence, Juneau, Alaska, USA.

Marcotte, J. 1990. Subsistence harvest of fish and wildlife by residents of Galena, Alaska, 1985-86. Technical Paper 155. Alaska Department of Fish and Game, Division of Subsistence, Juneau, Alaska, USA.

Marshall, C., and G. B. Rossman. 1995. Designing qualitative research. Sage, Thousand Oaks, California, USA.

McKenzie, D., Z. Gedalof, D. Peterson, and P. Mote. 2004. Climate change, wildfire, and conservation. Conservation Biology 18(4):890-902. http://dx.doi.org/10.1111/j.1523-173 9.2004.00492.x 
McNeeley, S. M. 2012. Examining barriers and opportunities for sustainable adaptation to climate change in Interior Alaska. Climatic Change 111:835-857. http://dx.doi.org/10.1007/s10 584-011-0158-X

Namey, E., G. Guest, L. Thairu, and L. Johnson. 2008. Data reduction techniques for large qualitative data sets. Pages 137-161 in G. Guest, and K. MacQueen, editors. Handbook for team-based qualitative research. Altamira, New York, New York, USA.

Natcher, D. C., M. Calef, O. Huntington, S. Trainor, H. P. Huntington, L. DeWilde, S. Rupp, and F. Stuart Chapin III. 2007. Factors contributing to the cultural and spatial variability of landscape burning by native peoples of Interior Alaska. Ecology and Society 12(1):7. [online] URL: www.ec ologyandsociety.org/vol12/iss1/art7/

Nelson, R. 1983. Make prayers to the raven. University of Chicago Press, Chicago, Illinois, USA.

Nelson, J. L., E. Zavaleta, and F. S. Chapin, III. 2008. Boreal fire effects on subsistence resources in Alaska and adjacent Canada. Ecosystems 11(1):156-171. http://dx.doi.org/10.1007/ $\underline{\mathrm{s} 10021-007-9114-\mathrm{Z}}$

Osherenko, G. 1988. Can comanagement save Arctic wildlife? Environment 30(6):6-35.

Ostrom, E., M. Janssen, and J. Anderies. 2007. Going beyond panaceas. Proceedings of the National Academy of Sciences 104(39):15176-15178. http://dx.doi.org/10.1073/pnas.0701886104

Pearce, J., and L. Venier. 2005. Small mammals as bioindicators of sustainable boreal forest management. Forest Ecology and Management 208:153-175. http://dx.doi.org/10. 1016/j.foreco.2004.11.024

Petty, A., J. Alderson, R. Muller, O. Scheibe, K. Wilson, and S. Winderlich. 2007. Kakadu National Park Arnhemland Plateau fire management plan. CSIRO, Jabiru, NT, Australia. [online] URL: www.environment.gov.au/parks/publications/kakadu/ pubs/fire-plan.pdf

Platt, R., T. Veblen, and R. Sherriff. 2006. Are wildfire mitigation and restoration of historic forest structure compatible? A spatial modeling assessment. Annals of the American Association of Geographers 96(3):455-470. http:// dx.doi.org/10.1111/j.1467-8306.2006.00700.x

Public Law 96-87-96 $6^{\text {th }}$ Congress. 1980. Alaska National Interest Lands Conservation Act.

Pyne, S. J. 2001. Perils of prescribed fire: a reconsideration. Natural Resources Journal 41(1):1-8.

Pyne, S.J. 2004. Pyromancy: reading stories in the flames. Conservation Biology 18(4):874-877. http://dx.doi.org/10.1111/ j.1523-1739.2004.00490.x
Pyne, S. J. 2010. America's fires: a historical context for policy and practice. Forest History Society, Durham, North Carolina, USA.

Quigley, T. M., and H. Bigler Cole. 1997. Highlighted findings of the Interior Colombia Ecosystem Project. U.S. Forest Service, Pacific Northwest Research Station, Portland, Oregon, USA.

Ray L. 2011. Using Q-methodology to identify local perspectives on wildfires in two Koyukon Athabascan communities in rural Alaska. Sustainability: Science, Practice, \& Policy 7(2). [online] URL: sspp.proquest.com/ar chives/vol7iss2/1011-061.ray.html

Reynolds, J. F., D. M. S. Smith, E. F. Lambin, I. B. L. Turner, M. Mortimore, S. P. J. Batterbury, T. E. Downing, H. Dowlatabadi, R. J. Fernandez, J. E. Herrick, E. HuberSannwald, H. Jiang, R. Leemans, T. Lynam, F. T. Maestre, M. Ayarza, and B. Walker. 2007. Global desertification: building a science for dryland development. Science 316 (5826):847-851. http://dx.doi.org/10.1126/science.1131634

Riordan, B., D. Verbyla, and A. D. McGuire. 2006. Shrinking ponds in subarctic Alaska based on 1950-2002 remotely sensed images. Journal of Geophysical Research. 111, G04002. http://dx.doi.org/10.1029/2005JG000150

Rist, L., R. U. Shaanker, E. J. Milner-Gulland, and J. Ghazoul. 2010.The use of traditional ecological knowledge in forest management: an example from India. Ecology and Society. 15 (1):3. [online] URL: http://www.ecologyandsociety.org/vol15/ iss $1 /$ art $3 /$

Rocheleau, D., B. Thomas-Slayter, and E. Wangari. 1996. Feminist political ecology: global issues and local experiences. Routledge, New York, New York, USA.

Rupp, T. S., M. Olson, L. G. Adams, B. W. Dale, K. Joly, J. Henkelman, W. B. Collins, and A. M. Starfield. 2006. Simulating the influences of various fire regimes on caribou winter habitat. Ecological Applications 16(5):1730-1743. htt p://dx.doi.org/10.1890/1051-0761(2006)016[1730:STIOVF]2.0. $\mathrm{CO} ; 2$

Russell-Smith, J., P. G. Ryan, and R. DuRieu. 1997. A LANDSAT MSS-derived fire history of Kakadu National Park, monsoonal northern Australia, 1980-94: seasonal extent, frequency and patchiness. Journal of Applied Ecology 34 (3):748-766. http://dx.doi.org/10.2307/2404920

Schoennagel, T., C. R. Nelson, D. M. Theobald, G. Carnwath, and T. B. Chapman. 2009. Implementation of National Fire Plan fuel treatments near the wildland-urban interface in the western U.S. Proceedings of the National Academy of Sciences 106(26):10706-10711.

Schoennagel, T., T. Veblen, and W. H. Romme. 2004. The interaction of fire, fuels and climate across Rocky Mountain 
forests. Bioscience 54(7):661-676. http://dx.doi.org/10.1641/ 0006-3568(2004)054[0661:TIOFFA]2.0.CO;2

Shenoy, A., J. F. Johnstone, E. S. Kasischke, and K. Kielland. 2011. Persistent effects of fire severity on early successional forests of interior Alaska. Forest Ecology and Management 261(3):381-390. http://dx.doi.org/10.1016/j.foreco.2010.10.021

Slocum, R., L. Wichart, D. Rocheleau, and B. Thomas-Slayter. 1995. Power, process and participation: tools for change. Intermediate Technology, London, UK.

Steelman, T. A., and C. A. Burke. 2007. Is wildfire policy in the United States sustainable? Journal of Forestry March 2007:67-72.

Stephens, S. L., and L. W. Ruth. 2005. Federal forest-fire policy in the United States. Ecological Applications 15 (2):532-542. http://dx.doi.org/10.1890/04-0545

Tashakkori, A., and C. Teddlie. 1998. Mixed methodology: combining qualitative and quantitative approaches. Sage, Thousand Oaks, California, USA.

Tiedemann, A., J. Klemmedson, and E. Bull. 2000. Solution of forest health problems with prescribed fire: are forest productivity and wildlife at risk? Forest Ecology and Management 127:1-18. http://dx.doi.org/10.1016/S0378-1127 (99)00114-0

Trainor S. F. 2006. Emergency fire fighting crew management study. Operations Committee of the Alaska Wildland Fire Coordinating Group, Fairbanks, Alaska.

Trainor, S. F., M. Calef, D. Natcher, F. S. Chapin, III, A. D. McGuire, O. Huntington, P. Duffy, T. S. Rupp, L. DeWilde, M. Kwart, N. Fresco, and A. L. Lovecraft. 2009. Vulnerability and adaptation to climate-related fire impacts in rural and urban interior Alaska. Polar Research 28(1):100-118. http://d x.doi.org/10.1111/j.1751-8369.2009.00101.x

Tsing, A. L., J. P. Brosius, and C. Zerner. 2005. Introduction: raising questions about communities and conservation. Pages 1-34 in J. P. Brosius, A. L. Tsing, and C. Zerner, editors. Communities and conservation. Altamira, Walnut Creek, California, USA.

United States Fish and Wildlife Service. 2008. Interagency FMP template. [online] http://www.fws.gov/fire/fmp/development/ interagency template final09_19_07.doc. Last accessed February 23, 2012.

Varner, M. J., III, D. Gordon, F. E. Putz, and K. J. Hiers. 2005. Restoring fire to long-unburned Pinus palustris ecosystems: novel fire effects and consequences for long-unburned ecosystems. Restoration Ecology 13(3):536-544. http://dx.doi. org/10.1111/j.1526-100X.2005.00067.X
Verbyla, D. 2011. Perspective: browning boreal forests of western North America. Environmental Research Letters 6 (4):041003. http://dx.doi.org/10.1088/1748-9326/6/4/041003

Viereck, L. A. 1983. The effects of fire in black spruce ecosystems of Alaska and northern Canada. Pages 201-220 in R.W. Wein, and D. A. Maclean, editors. The role of fire in northern circumpolar ecosystems. John Wiley and Sons, New York, USA.

Watson, A., and O. Huntington. 2008. They're here- I can feel them: the epistemic spaces of Indigenous and Western Knowledges. Social and Cultural Geography 9(3):257-281. http://dx.doi.org/10.1080/14649360801990488

Wengraf, T. 2001. Qualitative research interviewing: biographic narrative and semi-structured methods. Sage, London, UK.

Werner, R. A. 2002. Effect of ecosystem disturbance on diversity of bark and wood-boring beetles (Coleoptera: Scolytidae, Buprestidae, Cerambycidae) in white spruce (Picea glauca (Moench) Voss) ecosystems of Alaska. Research Paper PNW-RP-546. U.S. Department of Agriculture, Forest Service, Pacific Northwest Research Station, Portland, Oregon, USA.

Westerling, A. L., T. J. Brown, A. Gershunov, D. R. Cayan, and M. D. Dettinger. 2003. Climate and wildfire in the Western United States. Bulletin of the American Meteorological Society 84(5):595-604. http://dx.doi.org/10.1175/BAMS-84-5-595

Westerling, A. L., H. G. Hidalgo, D. R. Cayan, and T. W. Swetnam. 2006. Warming and earlier spring increase Western U.S. forest wildfire activity. Science 313(5789):940-943. htt p://dx.doi.org/10.1126/science.1128834

Westerling, A. L., M. G. Turner, E. A. H. Smithwick, W. H. Romme, and M. G. Ryan. 2011. Continued warming could transform Greater Yellowstone fire regimes by mid-21st century. Proceedings of the National Academy of Sciences 108 (32):13165-13170. http://dx.doi.org/10.1073/pnas.1110199108

Western, D., and R. Wright, editors. 1994. Natural connections. Island Press, Washington, D.C., USA.

White House. 1994. Government-to-government relations with Native American tribal governments. [online] URL: htt p://www.justice.gov/archive/otj/Presidential Statements/presdoc1. $\underline{\mathrm{htm}}$

White House. 2002. Healthy forests: an initiative for wildfire prevention and stronger communities [online] URL: $\underline{\text { http://w }}$ ww.fs.fed.us/projects/documents/HealthyForests_Pres_Policy\% 20A6_v2.pdf 
Wolken, J. M., T. N. Hollingsworth, T. S. Rupp, F. S. Chapin, III, S. F. Trainor, T. M. Barrett, P. F. Sullivan, A. D. McGuire, E. S. Euskirchen, P. E. Hennon, E. A. Beever, J. S. Conn, L. K. Crone, D. V. D'Amore, N. Fresco, T. A. Hanley, K. Kielland, J. J. Kruse, T. Patterson, E. A. G. Schuur, D. L. Verbyla, and J. Yarie. 2011. Evidence and implications of recent and projected climate change in Alaska's forest ecosystems. Ecosphere 2(11):art124. http://dx.doi.org/10.1890/ $\underline{\text { ES11-00288.1 }}$ 


\section{APPENDIX 1: Sample of Quotes Organized by Category}

Note: This is a sample to show how quotes were organized by topic and does not include all topics or all quotes for listed topics.

\section{SEVERITY (FIGURE 2)}

\section{Factors driving Severity}

\section{Fuel Type}

Because there's, if you got a fire in the big timber like we have here, it'll be hard to uh, get it out. It'll be really hard to get that fire out when it just burn right through it, nothing will stop the fire.

and some places here, down here on the, like, on the hills, there'll be a fire started, could be, uh, it'll just burn up. It'll burn up by itself and you can't really do much for it. It, uh, it, brush is too thick. You know.

The brush, uh, call it jack spruce, they're small, small trees, but they're, uh, so thick that once the fire get in there it, it'll just keep burning, burning until it burned out.

I'd say it, well, some areas it burns. Depends on the, dead fall, and all the bark beetles that's been here, through the area and stuff, and, I'd say it's, you know, just depends on the, on the material. Some'll burn hot, some won't, you know. And then when they, when I saw a burn a long time was back in 60, late 60, and the fire just started at Kobuk and ended at the Yukie up here. And it burned all the way to October.

\section{Conditions}

'cause it's windy and it's so dry, the grasses are that tall, and it's just like, gas on paper and then watchin' it explode.

'Cause when fire moves and it's unpredictable, and the wind helps it.

it was no time, in one hour, just burned. So dry if there was a fire it's really so dry that it'd be hard to fight.

That the way it was burning, nobody would believe that fire would burn like that. The flames were goin' straight across. That's how fast it was goin'. Just from, not this way, you know. The flames were blowin' and it was, came to the road we were on, it just blew, the flames just, we were goin' so straight at it, you know.

Yeah. Well, there's just a lotta dry stuff out there, that burnt from that previous fires, but, uh, sometimes it's just like it moves in certain areas every year and, uh, you don't come back to the same place every year, you know. So it changes, just depends on the fuel, I guess, and the season. Yeah, how much it dries out, but every year it's dryin' out more and more, you know. Getting' hotter and hotter. 
I've seen that, where, you know, grass fire and all of a sudden the fire, it's just ground fire mostly, 'cause it's cool in the mornings and the fire just creeps along, and it leaves a lot of those trees green, you know. And it's burning slow and not burning hot. And I've seen some where it's burning hot, and, uh, and it seems like it just skipped across the trees, you know, and didn't hardly touch anything on the ground, you know. Yeah. Depending on the wind, you know. And how dry the fuel is. So it, it changes every year. You know, it will continue to change, you know. We're either gonna get more fires later on or we're gonna get hardly any. I seen where it rained... long, used to rain the whole summer, start in June that don't quit until the end of August.

Um, and especially now, I would guess that if fires went through some of those areas, no doubt fires have gone through in the past. But l'd say they're more vulnerable now. Uh, because of the permafrost melting. They're probably very vulnerable, some of it

The willows, the willows don't fall. They burn, yeah. But they'll, uh, sometimes they burn and then sometimes sometimes they won't. You know, depending on how hot the fire was, you know.

When it's overgrowth it does burn fast once it gets started, especially with the sun and the wind.

\section{Severe Wildfire Effects}

Oh, the, uh, it's really, really, two of 'em in particular, um, just, I think burned so hot and so long that they, it just kind of, sort of turned that area into a moonscape, I think. It's empty, there's, uh, you know this, you hear scientists saying that it's better for, for, uh, moose and animals that browse and all that, that's nonsense. The fires that are more across the surface, are that way, you know, and stuff grows over, but the deep burn ones, they just, are no good for, well there's areas right up here, north of Galena, north of Bear Creek, that still nothing in 'em for, been 40 years now

Uh, there, uh, that hill burned, that was about 20 years ago. This side of my cabin about 5 miles. But that was a big burn. And it's just now growing back to where there's animal in there. After 20 years. But then, if it's different um, different soil that was left, I think, a very thin soil layer that, that the plants grow in and I remember that was just sad and so forth. And, and the last, probably four or 5 years there's finally, you know, rabbits, and moose livin' in that area, wintering in that area. Uh, so it's now turning good again, whereas before, you know, when I first started trappin' that area it was good trappin'. Now it's just finally come back after 20 years.

And then if you get a big fire goes through there, sometimes, if it's deep enough, where all the trees fall over, you have to cut it all out again.

But it's, it's an area where it once, probably once burned really, really too hard, because, um, uh, it's not that brushy.

\section{Moderate Wildfires}

Depends on if there's, if there was enough seedlings there to, to regrow it. Uh, lots of times it, it, when a fire goes through, it burns over the top. It doesn't burn down in the roots. Uh, unless the, the peat catches on fire and the moss catches on fire, and then it burns it out underneath. But in over the top, 
uh, it usually doesn't burn clear to the ground it flashes on, all the dry stuff on the top. So the, the stuff would regrow again. Because just the top of it burned up. Not the root section, and the main trunk. The main trunk would still be there. So, and it would make a lot of, the ash would make fertilizer and so the stuff would grow again fast.

Well, one place, well, one place that burned around Nulato was before my time. And, um, it, um, what fire does is it burns what, a lot of times it depends on how hot it is, or what kind of fuel is there, but if it's basically a swampland, like over in the Kaiyuh flats, it'll burn through right away and it'll basically just be a ground fire. Um, well, what happens is that, you know, a ground fire will actually, um, you know, because it burns the way, all the dead that's out there, it's primarily good for what's left, because it, the ash and what's left is actually good fertilizer. So a lot of times, willows will start up really quick, like in the first couple years, and that'll be really a good moose browse. It's actually good for the moose population. And a lot of areas, ... you know, it's good for the berries,

there's been a couple of fires the last, well actually last 3 years up in that area. Uh, they're a more surface burn and kind of, uh, interesting. There's some, um, area that grow that fast.

\section{CHANGES IN LANDSCAPE AND CLIMATE INFLUENCING LANDSCAPE FLAMMABILITY (FIGURE 3)}

\section{Overgrown Vegetation}

it's getting warmer so everything is growing up, closing into the places there's cranberries. I remember it used to be wide open, now it's uh, it's all grown over, you know.

\section{Milder break up/ Less flooding in lakes and sloughs}

Oh, yeah, we go to uh, high ground when there's a lot of snow. They know it's gonna be high water. Old Town did flood. Uh-huh. So everybody stay in the high ground like here. Uh-huh. Us too. Yeah. Water all over. Yeah. And, uh, whole time we stayed in high ground. Nice. Just one hill, just alone. And then on the other side it's all hilly. And there we stayed. Mmm, everywhere it's like ocean. Lots of water. Right now everywhere is grass lake. No water.

Yes! I remember when water used to get high, we used to ride around way back big Willow Lake he's talkin' about. We used to drag the motor around all over. Now water never get that high for how many, thirty years?

Them years but uh, the river break up, the ice break up was more, uh, more violent, I guess. But we camp, our camp was, oh, probably 4 miles, maybe, maybe, between 4 and 5 miles as the crow flies from the river. Yet we could hear the breakup. Yeah. So it was really loud, you know, trees breaking, big trees and all that. So it was pretty loud.

Because Kaiyuh is that rich. And it still is now, but uh, it's not gonna be much longer, because, uh, you know, and global warming is beginning to take its effect up there now, you know, and it's more in the form of drier summers and uh, shorter winters, I mean seems like, I don't know, every other year is 
different, you know, some years you have very little snow, other years you have a lot of snow and, uh, but, uh, the bottom line is the lakes are dryin' out. You know, uh, I can remember back in, every spring you had high water or you have floods, or but the lake was filled with water. And that doesn't happen no more. You don't hardly ever see that. I think the last flood we saw in, Nulato is build on a 25 years flood plain. And, uh, we haven't seen a flood down there since sixty - the last big flood was in 1963. So it's been quite a while. So they're due for a flood, but, but from '63 to now, our water never gotten high, high, high enough to fill our lakes so that they stay filled with water, you know, so now the vegetation's taken over. And it's happening all over the, the Interior on the lakes. It's really noticeable. And Kaiyuh's no different, you know.

\section{Permafrost thawing}

It used to be like a lot of willows in really deep water and permafrost when the land was cold and other animals were able to survive, because they're cold water animals. Well, they, in my time l've seen all the, lot of lakes dried up where there used to be a lot of water, and beavers in there and all the, it's just that dry grass there, ready for burnin'.

The lakes are drying up, and where they used to be nice ridges of ground, it's just sinking. All that permafrost is thawing out. Like back here, where we call Long Lake spring camp. That, the hill used to go all the way back, all the way across, that used to be high. High ground. Now all you see stumps in the water sticking up. That's all, all that warm weather's really thawing the permafrost out, you know.

Oh, yeah. Um, that area's, uh, a lot of that area, the, the lakes are drying out. Uh, I dunno, I suspect it's from, from, uh, maybe the permafrost is melting and it's just allowing drainage. And so, uh, it's huge, huge areas that were, were, uh, you know, water-filled lakes there are now these grass lakes and, and, uh, some of those big, big lakes that were full of water in, uh, for instance late '60s, early '70s are, they're all grown over now.

Um, and especially now, I would guess that if fires went through some of those areas, no doubt fires have gone through in the past. But l'd say they're more vulnerable now. Uh, because of the permafrost melting. They're probably very vulnerable, some of it.

You know, when they, like when they used to have 50, 60 below 0 winters, the permafrost, it holds back a lot of, uh, moisture that go into the ground.

\section{Drying lakes}

This Fish, place they call Fish Lake down here. Long time ago that place used to be, well it's still known today as, uh, the native name is Fish Lake. But, uh, if you translate it, the native name say that's where they catch fish. They call it Fish Lake. And it's known for the white fish. Just a lotta really fat white fish in that lake. And, then, the people, people that lived there was my wife's parents, they lived in that area. Had spring camp there. So spring time they set fish net in there. Then they, they, uh, catch the fish, they cut it and they hang it and there's hook holes. And my uncle Steven told me after they're done huntin' muskrat, huntin' up that way them flats, instead of comin' to here, they go on to there. Because they 
know that there's a lot of fish down there. There's good fish, they can eat fish. And in their smokehouse where they hang the fish, the ground is just greasy. Because the fish, you know that's drying, the grease drip. And that's how rich the fish was. So they just made this special trip down there just to eat that fish. So, and then this spring, I went down to that lake. Me and (name). We drug a canoe back to that lake, one mile, over a mile. We drug that canoe back to that lake. There's no water in that lake.

One of us who had nothin' to do would snowshoe up on the north side of Bear Creek and get kind of in the low hills back there. We found some beaver houses that were in 'em, what you call Bow Lakes. And some of the beaver houses were, I would say, good 20, 30, 35 feet above the water level. And it, it had a lot of water back some time, you know. And gradually it's been goin' down, goin' down like that, so. And there, like when I was a teenager, you know, we used to go along these roads up there, kids ride and haul our canoes up there. And any one of those lakes up here, we'd, uh, haul our canoes right in the lake, paddle back and carry it over to another lake and paddle and you can't do that anymore, 'cause all those lakes are grass lakes most of 'em. Dried out. I tried that about 10 years back, I bought a canoe from Ruby and paddled back so far and the rest of the lake was dried out. I thought, he heck with that!

Cripe! he just walk all over the place where we used to go with boat!

Steamboat, they call it. We seen that kind lotsa time. When I was kid. And even that boat can't come around here hardly.

And that's where they used to hunt long ago. With canoe. And that's where, where we used to stay. It's this low creek, deep water. Right now here, and there's big bowl. No water. Gee! Just can't believe it. And no muskrat.

We never thought that it's going to be like this. Always muskrat. Always fish. Now the lakes is dry. Just like me and my husband one time, we were in the camp, so we start to go, used to be our trap line. Can't believe that's the place. What was lakes, all grass. And middle of those places, big willows. Gee, only place I remember is that willow tree. That's all. In this one place there's a creek and there's a mink den right there. We used to just trap for mink all the time. We see that. We seen it. But no water. My, talk about, I think about it sometime. Honest we gonna get lost. My! My! I sure think about it long time after.

\section{Drier vegetation}

Oh, there's tons of it, whole forest is dried up. Not whole forest, but l'd say miles. Like, mile and a half, two miles, even up to three miles of trees. Tree stands are just dryin' out. Find like thirty cords where there used to be all green trees. 'Cause the lakes are dryin' up, I guess.

And, I've seen that there where you can trap for miles and it's just dried up and you don't see anything. .... That would be like, I say, that place is just dried up, all the woods are dry. uh, it's just a dry, looks green, but it's dry. 
all that rain, and all those flood lakes used to be long time ago is just sinkin' into the ground, you know.

That's from lake to lake, and finally, you have to cut brush. There's no brush to cut. It's all dried up and fell down. 'Cause of the permafrost melting.

Where you have to start watering trees and stuff, you know you're in trouble. You know it's dry, you know.

\section{Loss of fire breaks}

Right now is worse because, you know, all the lakes dry out! If there's fire around here on these flats, there's nothing can hold it back 'cause all, just the lakes are all dry! No water. Man! People used to go down there, at Uncle Edwin's camp. Fish Lake they call that place. Big lake! Everybody used to go there in spring time to have fish net under the ice. Just when the fresh snow and uh, fat, everybody, used to be really fat white fish. Man! And right now is just little hole out in the middle, that's all. All dry. Not no water!

\section{More lightening}

One elder explained that she didn't see fires start because in the past "You never heard thunder...we never seen fires start. Right now it does. So when there's thunder, we hear thunder we're scared. Sure enough. See it starts, see the smoke."

\section{Less Rain}

Well, I think it's better to put it out because, 'cause it don't rain like long time ago and there's hardly no water. All the grass lake is dry. Grassy lakes are dry. And there's no way it'll go out.

\section{Milder winters}

Long time ago weather used to be cold. Weather is so cold. What, what I used to hear is fox tail used to freeze. Yeah. And dog's tail too, they said.

We used to see more richer land when there was 50,60 below zero in wintertime. What I see and that's to me, back in those days was healthier. Healthier, uh, forest. Less fires. You know. Lotsa rain, off and on. So that's the way I look at it, I look with global warming it's hot all the time. Dry. We get rain, but not as hard as it used to be. Like in August, probably middle of July or something used to be our rainy, rainy, uh, season. That was, maybe before September then everything start getting cold. So, I see, to me, I see, I think, uh, back in the cold weather days I think I see more richer land than I see today.

Uh, and when I say cold, I mean it used to be really cold. You know, like, .... like for the whole month of January, and the whole month of February, for some years in my younger days it never used to get less than 50 below for those two months.

\section{Unpredictable weather}


You know with this weather anymore, it's so crazy you can't - like, the last time I trapped there, really I had traps for wolves and back there it was really bad for trapping because you know, it would melt, and the ice, and the traps would freeze solid, and - so a lot of people just went for snares.

\section{Later freeze up}

But, uh, that was fun. We moved down there in May 13, we went down there, and we came back here on October $2^{\text {nd }}$, that's how long the summer. And long time we used to move down there on June 1 , first week of June, right after school is out, uh, May 23, or something, that school was out, our kids, we move down there, that was in '80s. we live in camp. And then we' $d$ come back right before school starts, sometimes August 21, and then freeze up by Sept. 10 or somethin'. Not anymore! Last year it was almost November it was, never freeze up.

We used to get a lot of rain in September, and now we hardly even get that. The snow is comin' later. You'd see snow in October, everything was froze over in October, I seen it froze over in September, September 14, and was froze solid around here. You know, first week in September. And, uh, haven't seen that in quite a while.

Yeah, not, not that, it's just, ah, I dunno, it's, uh, seems like the freezeups we have are a lot warmer and its not safe to go on the ice right away, and then you know, we don't have enough snows, so it's too rough to cross those, grass hummocks and stuff, you know, then you gotta have maybe a foot and a half of snow where it'll stay on top.

\section{Use of term "Global Warming or Climate Change"}

So what happened is that, uh, the water that was formed around that island, you know. That water it keep eating away on the, the permafrost on the bottom, it just sink. So that's the way we, we, uh, we figured it. You know. That's what's happened. Like they say, you hear the news all the time. Global warming. (laughs) Yeah.

Uh, I know the climate's changed. Yeah. Lot. Uh-huh. You know, back then, when I was like about 10, 12 years old, we had cold weather. All winter. We were used to 50 below. All winter long.

\section{Earlier Green up}

you just have to stop hunting, everything, because that's when they have young ones and I think it was when the leaves first come out. But it used to come out two weeks later in those days.

\section{Hotter drier summers}

The permafrost is melting. That's what's changing, that's why all that erosion, the permafrost, everything's getting hot. Last summer we came up here for $4^{\text {th }}$ of July, that's the hottest I notice it. You know, 90's is really hot, 80 's is very hot. But when we came here and they were having bike races, everybody was hosing each other down. And then this one guy said down at his house it was hundred and two degrees. I believed it. 
it got really hot, you've got to keep your head covered. You burn. You have to, it's too hot. So it is getting hotter.

\section{New Places burn}

Um, the fires was always way out from the village. And back then they did not, uh, fight the fires at all. You know. They just let it burn out. As long as it wasn't close to the area. But just lately it seem like it, it's, it's in, anywhere just burns. Like up in Ruby also, out where we go pickin' berries, that was burned out.

And the forest fires has a lot of, change a lot of difference too, 'cause there's a lot of fires all over, you know.

\section{Longer fire season}

Fire starts earlier and burn longer. Yep.

Increased risk

A lake that's all dried up and full of grass, it, it burn like a mine in just a few minutes and probably no escape.

Last year there was, uh, so much grass. You know, the grass just grew here about, four feet. All over! About every lake. So that was, uh, what I see last year. You come to the lake, look, you look around for a moose you could just barely, uh, look over grass, grass is so long. So that's, uh, that was last year. And, uh, early this spring we went out, you know, walking around in the woods. Um, all that dead grass was just layin' on the ground. You can't set fire anywhere. You can't build a fire anyplace, it's just, it's just dry.

\section{DRIVERS FLAMMABLE CONDITIONS (FIGURE 4)}

\section{Dead or dry vegetation}

\section{Spruce Beetle}

The bugs. You know, like there's been, how many years ago they were saying that, uh, there's a whole bunch of certain kind of bugs in trees, you know, and I could tell that back here that, um, there's something wrong with some of these trees because, um, they're all brown, they just turn brown. So I think they must have bugs. Uh-huh. And then you look at other trees and they're nice and healthy.

You know, like, I know that the crops there, on that land, there's, uh, those trees, they look like something is just eating them. They're ... getting dried up like it burnt or something, but there's no fire. Seem like there was just, um, lot of, um, trees that was eaten by beetles. In that it was kind of just dried out and dead. And it burned up 
It's, there's too much dry, dry trees, beetles are eating them. It's really thick. That fire really, it was coming this way, and then the wind shifted, and it went, and then it went right back into the burned area.

\section{Road Chemicals}

You know, do you think a lot of that, lot of it is close to the roads though. I think a lot of it's that stuff they put on the roads in the summertime. I think that has a lot to do with it.

\section{Wildfire}

Well, you could see there's, all the trees are dry. Burned up.

Well, there's just a lotta dry stuff out there, that burnt from that previous fires,

Yeah, I saw, uh, there was forest fire all the way, from way out Huslia River, all the way on the hill all the way out to the, uh, Huslia River and over this way, but uh, uh, all that was burned up about, maybe 20 or 30 years ago. And all the, there's a lotta dead trees on the ground.

\section{Landscape drying/lakes converting to grass}

Oh, there's tons of it, whole forest is dried up. Not whole forest, but l'd say miles. Like, mile and a half, two miles, even up to three miles of trees. Tree stands are just dryin' out. Find like thirty cords where there used to be all green trees. 'Cause the lakes are dryin' up, I guess. it's a fire hazard, yeah.

A lake that's all dried up and full of grass, it, it burn like a mine in just a few minutes and probably no escape.

Well, I think it's better to put it out because, 'cause it don't rain like long time ago and there's hardly no water. All the grass lake is dry. Grassy lakes are dry. And there's no way it'll go out.

Last year there was, uh, so much grass. You know, the grass just grew here about, four feet. All over! About every lake. So that was, uh, what I see last year. You come to the lake, look, you look around for a moose you could just barely, uh, look over grass, grass is so long. So that's, uh, that was last year. And, uh, early this spring we went out, you know, walking around in the woods. Um, all that dead grass was just layin' on the ground. You can't set fire anywhere. You can't build a fire anyplace, it's just, it's just dry.

I mean, it used to be full of water. It's all dried up. And that causes the grass to come up, so the grass sucks up all that water too. And so the grass gets higher.

Mostly the lakes that are dryin' up are turning into grass and there's, and there's, I guess hardly nothin' can survive in 'em, l'd say, uh mosquitos. (they laugh) But, um, I don't know what eats grass, just moose, maybe. You know, maybe birds, I don't know, I'm not sure, but uh, it's kinda like a grass that nothin' can survive on, it's a tall dry grass that's just good for burnin', I don't know what else. It used to be like a lot 
of willows in really deep water and permafrost when the land was cold and other animals were able to survive, because they're cold water animals. Well, they, in my time l've seen all the, lot of lakes dried up where there used to be a lot of water, and beavers in there and all the, it's just that dry grass there, ready for burnin'.

\section{Grass from humans}

And where they make trail it's all grass now. Especially out there by the lagoon. When we were doin' town cleanup the other day I noticed that grass get about, that's about 3 feet high.

But not in the town. Like even right back here along this hill right here, this whole place is all grass and about this thick, you know, top soil. That'll burn really hard.

The way I look, I mean. But um, my cabin I've been trying to build a fire break around it, I, it's filled up with leaves and grass every year so it's a yearly thing. And every year I hear people burn the grass right along the airport where it's a real fire hazard. A fire can move, like, you know, a mile in a few minutes, and people can't run.

\section{Unknown deadfall}

Lot of blown down trees. Maybe because the roots are getting weak or the, it's just, I don't know. Hasn't it changed? Lot of big trees are falling over.

\section{Natural Mortality}

Trees gonna die anyway

\section{Thick trees}

That is not really too thick, where you come to a birch patch and it's really thick. Those, those are too, they, uh, they get too much water and they're kinda dried out like. Then there's too much, too much, uh, too much trees in one place and then they start drying up right away, it takes too much to keep that tree maintained at, you know.

\section{Jack Spruce}

Those spruce trees? And then they're not green, they're dry. And the whole forest is like that, down right outside of town. That's because, uh, um, that burn there a long time ago, that's how they grew back. But they're so close together.

jack spruce, they're small, small trees, but they're, uh, so thick that once the fire get in there it, it'll just keep burning, burning until it burned out.

Um, it was jack, jack spruce. Seem like they, you know, where there's lots of, you can't do nothing with those ones when they catch on fire. You have to wait till, what we usually do is just trench from lake to 
lake before it get there. Try to hold it back with, you can't, you can't do. Llook behind you! Yeah. Yeah, that's the hardest, was jack spruce to jack spruce.

\section{Thick brush}

a lot of places where we could walk and travel, it's so thick and grown up and bushy, we can't walk through it anymore. Uh, but I don't know how they'd control it, so where it would just, if there happened to be a fire there

\section{Time since wildfire}

it's better to let it burn 'cause it's gonna burn sometime. Sooner or later it's gonna burn up. They keep getting the fire out before it even, uh, starts, I mean, uh, before the forest fire. That's why it's so hard to get the fire out, because it's so, they let it get so thick, the trees get so thick and, once it, the fire starts and they can't get the fire out, it's just, it just keep kinda grow I know what, uh, areas that never burn for years and years, just gets worse and worse and so when the fire does come, you know, everything will burn. Like this whole hill right here that we live on, this place burn before too. that's why there ain't no brush all over, you know, there's like this much top soil or whatever.

\section{Less human use}

Nice little cabin, it's all brushed in.

\section{Rabbits}

You can't even see the lakes anymore, they grow so fast. I say, a lot of it has to do with, you know, we used to have a lot of rabbits.

\section{Getting warmer}

it's getting warmer so everything is growing up, closing into the places there's cranberries. I remember it used to be wide open, now it's uh, it's all grown over, you know.

\section{POSITIVE AND NEGATIVE EFFECTS OF WILDFIRES (FIGURE 5)}

\section{Fire ruins country}

I went around there but there was nothing there. Still kind of burned, just different land altogether after it burned up.

But most of the country where a lot of animals been born, the State took over, you know, the State of Alaska. Took over the land. And they let the country burn right up. But the state would, can't afford to have firefighters knock it out, you know. Lettin' big countries burn up, you know. I don't know why they allowed the state to take over the country. They're gonna kill the country.

\section{Fire kills small animals}


You know young was born in May, and they can't help themselves these small marten, you know. They're born in the den, and they burn right up, you know. Nothing you can do, even the mother burn too, I think, but it's that, they can't, no place for her to run, you know.

\section{MATURE SPRUCE-DOMINATED FOREST BURNS (FIGURE 6)}

\section{Small animals burn}

Well, I think it burned lotta marten, lotta small game. You know, like the martens, you know, they don't run. They'll climb trees. You know, they, they're tree climbers so they don't run from fire.

\section{Combat Spruce bark beetle}

And the idea was, some of it that burned I think was to stop the bark beetle or somethin', but that was, uh, it was a good idea at the time. I thought.

\section{New growth-willows, birch}

\section{Loss of habitat for furbearers living in old growth}

So anything in regard to wildlife that pertains to spruce trees, they're gone forever. They're not gonna come back. They don't, their, martens don't deal well in birch trees. Mink don't deal well in birch trees. Linx might, because they get rabbits. But all the other fur-bearin' animals will go where the spruce trees are.

\section{Food for moose, mice, rabbits, lemmings}

Uh, 'cause it opened up a, it opened up a big huge area. Uh, and so there was young, young growth after, after the fire burn and the young stuff sprouts up and so, uh, the different animals would come in and eat the younger vegetation. Then that, seemed like after a year then the, was like they were always there.

\section{Thick brush/birch hard for travel}

Yeah, no, and after a fire a lotta birch trees grow along the bank, and it, it made it tough to go back to the lakes 'cause the birch trees grow close together, they're harder to cut and everything else, so. But, uh, I don't know if the moose care too much for birch trees either. 'Cause I notice in that Bear Crick area there's not that many more moose like there used to be.

\section{Spruce grows}

It grows back that fast, yeah. The trees, spruce trees, you know, that's mainly what's up there.

\section{Jack spruce grows}

Yeah, it grew back too, but they're, they're all jack spruce. Where there used to be big tall spruce trees.

\section{Extensive deadfall}

Travel difficult/impossible/trails must be re-cut 
Well, the trees that burnt, all the trees fell over, and the stumps stickin' out all over. You can't go back to the same area. Where, like where you had quotas before, if that country burn up, then all those, trees fell over, the stumps come up too. All the roots, the roots come up and the roots standin' up like this, you know. They're like that all over the place. Where it burns. And you can't go through it. You have to go through like this, you know. Around all them stumps.

\section{Dry firewood}

Well, actually, if a fire burn close to a village we don't have to go too far to make rafts or, fall time spring time we go up the river and float down logs, both for firewood and for cabin.

\section{Habitat for birds and small animals}

Uh, more moose moved in. Some of the animals, some of the smaller animals moved in, into the, into the downed trees where the trees would make a protected area. Uh, oh, lots of more different kinds of birds.

\section{Deadfall blocks lake exits and kills fish}

Not since, not since, uh, fire burned up all the trees, trees fall over lakes and block off the creeks and wipe out a lot of fish in there. Not only on top of the land, but inside the lakes also.

\section{Loss of calving habitat for moose}

Well, you know, that the, it used to have nice heavy timber along both sides of Bear Creek. Used to be good for moose and stuff like this. You know, moose would have their calf and they, they like that shade. Where the spruce trees give you shade. After it burnt up they don't have any more shade, it's and then the other thing is, uh, when it was, the snow gets deep in the winter, always inside the spruce tree line the snow was not so bad. They can walk around good in there.

\section{Loss of shelter from wind and snow for humans and moose}

Yeah, because another problem with, uh, that area that burned over, uh, the wind blows in there. And, it, get drifted and a lot of the trailsite is (slanted) like this. It keep, it just drifted you know, the drift. And you go a long way you just have to stay sideways. And, because all those trees burned, they all fell down and then wind start blowin' and the snow piled up a certain ways and by the time it get there the trail is like this(slanted).

\section{Harder to hunt without cover}

Mmm, actually, all the trees would not be there if there's fire. And, we can see further in the woods, and if we can see further the animals can see us further too and they'll run off.

Loss of valuable large timber

It's probably pretty hard to find next, 'cause all the fires actually burned all the good timber.

\section{Timelag}

And when I say forever, I'm talking in terms of, like, 50 years. 60 years. Gonna take that long for that thing to regrow. The big trees, never. It'll take you another hundred years just to get a tree half the size of the one that burn up. The little guys, in the meantime, are gonna overgrow. Wherever there's spruce 
trees, fire come through there, and for the next 30 years all you're gonna have in there is gonna be alders and birch.

\section{NON-SPRUCE FEATURES BURN (FIGURE 7)}

\section{Overgrown, bushy area}

Well, if it's a brushy area I would, I would be happy that it burned out. So it will get more vegetation back in that area. More animals for our subsistence, more hunting for our subsistence.

\section{New growth attracts moose}

I'd like to see some of it, uh, because uh, a lot of places where we could walk and travel, it's so thick and grown up and bushy, we can't walk through it anymore. Uh, but I don't know how they'd control it, so where it would just, if there happened to be a fire there ... they let it burn. And they let it burn and, uh, in a season or two it makes new growth. And, uh, so a lot of animals kinda go back in there. Where they couldn't go before because the brush was too thick.

I think so too. Because they gotta have new, fresh vegetables. (they laugh). New willows, Especially the, especially the moose

So a lot of times, willows will start up really quick, like in the first couple years, and that'll be really a good moose browse. It's actually good for the moose population.

\section{Dry Vegetation Revives}

I mean, we're kinda happy 'cause um, we could get more moose in that area. More vegetation's coming out not so dried out. Uh-uh. .We were kinda, kinda happy it burned out there. 'Cause it was gettin' dried out and too, too thick with brush

\section{Human travel easier}

Kinda hard to get to places. Because of, um, brush, um, being too brushy and stuff. Then, then after that people, it was easy for people to make, uh, to travel, in that area.

\section{Rhubarb grows better}

(Rhubarb grows along) the river bank. Creek. Sometime, after a burn, we usually find more. But then they wipe out rest of the game and rest of the plants.

\section{Berry patch burns}

\section{Overgrown berries rejuvenate}

They got bigger. And then, the cranberries, I don't know how long ... they came back. And the blueberries. But the one that's slow is blackberries (crowberries). Gee, they took up just the same size every year. They're gettin' little bigger finally. So, some, some plant grow fast, I guess. 
in Kaiyuh area in some places there wasn't, where it burned there wasn't like, salmonberries. And now salmonberries is comin' back in that area. Probably because it's more open. More open, there's more light. There's more light getting there, in those areas. Yeah. Seem like when it's, um, place is blocked off, um, like lot of brush, along where the berries are, they hardly grow. 'Cause there's not enough sunlight. And see, after the area burn out, it's more open, seem like.

\section{Deep burn: berries replaced with something else}

(Q: Do berries re-grow after a burn?) Depends on if there's, if there was enough seedlings there to, to regrow it. Uh, lots of times it, it, when a fire goes through, it burns over the top. It doesn't burn down in the roots. Uh, unless the, the peat catches on fire and the moss catches on fire, and then it burns it out underneath. But in over the top, uh, it usually doesn't burn clear to the ground it flashes on, all the dry stuff on the top. So the, the stuff would regrow again. Because just the top of it burned up. Not the root section, and the main trunk. The main trunk would still be there. So, and it would make a lot of, the ash would make fertilizer and so the stuff would grow again fast.

Oh, yeah, there's a lot of places where you can see, uh, where it had burned before. You know, and uh, like say, they had big forest fires. Um, and, after after the fire, you know, everything starts growing. Like, say, over here, you know, and they had that big fire across the river, that goes right out to the bank? And I was saying, once things start going on there it's gonna be really good for berries, because Mom said, you know, they used to pick blueberries over there. Last summer there's some people went over there and said there was a lot of blueberries. Oh, yeah. Seem like they just really grow back because there's not, it's not brushy, it's all in the opened. That's where we lose all our blueberries, I think. Because they choked out with all these trees and willows, and everything.

\section{Berries to grass}

Yeah, they (berry patches) burn fast though. You know, I haven't, they don't mostly come back for years, like maybe 20 years, but uh, grass will pop up, grass and anything else. And it might, that might not give up the, um, space once it takes it.

\section{No need to burn functioning berry patch}

Um, they're, uh, fire is really dangerous for certain berry-pickin' areas, for example, like I recall one instance, when, um, back in the days when there would be families, or sometimes three or four families would go berry picking, you know, and camp out for a few days. Uh, and, uh, some of 'em started a little forest fire. Everyone had to pitch in and stop that thing. To not destroy this berry-pickin' spot that's, you know, everyone's gone to or everybody in that area, to pick cranberry.

\section{Less Berries}

they say after a fire it comes up a lot better. But I don't know. 'Cause, uh, over here where we used to go pickin' berries, that got all burnt up and, um, the berries is not as abundant. You know.

Takes time

It's hard to get the blueberries, it's gonna take a few years for blueberries to come back. 
It (cranberry picking area) burned up now, so maybe 10, 15 years down the road it might be good again. And, uh, just depends, 'cause it almost burned that whole area where I would pick cranberries every year. But it stopped just short of it. And it was good, you know, and then, another area would've been hard to find cranberries. Have to go further, that's all.

\section{Lichen burns}

\section{Caribou may leave}

Uh, yeah. I remember my grandma talking about, uh, as we were traveling along the river between Ruby and Kokrines, there were, uh, caribou that would come across. Uh, we didn't see it anymore because the herd moved because of the fires up around in this area. They would either move further, uh, west, or further east. So they didn't come through this, this area very often. But they did at one time. Uh, and because of the fire, yeah, uh, the caribou eat, uh, lichen, and, uh, type of moss. And so if the fire burns that out, uh, they wouldn't go there. They'd go someplace else where, they might move, uh, as much as a hundred miles.

And it takes 50 years for lichen to grow where the caribou food.

\section{SOIL OR ORGANIC MAT BURNS (FIGURE 8)}

\section{Soil composition changes}

we see brown sand, because it burned out a long time ago. Burned out hill.

Oh, the, uh, it's really, really, two of 'em in particular, um, just, I think burned so hot and so long that they, it just kind of, sort of turned that area into a moonscape, I think. It's empty, there's, uh, you know this, you hear scientists saying that it's better for, for, uh, moose and animals that browse and all that, that's nonsense. The fires that are more across the surface, are that way, you know, and stuff grows over, but the deep burn ones, they just, are no good for, well there's areas right up here, north of Galena, north of Bear Creek, that still nothing in 'em for, been 40 years now.

\section{Erosion}

And it, um, uh, when somethin' burns it washes out too. Rain just washes everything out. You know. You have to make a new trail, like a, we had pretty much cut out a whole new trail through that mountain after it burned. Not just one, not just one time. Every year.

Like the erosion, like, I think. Hills, like washouts, and all that, that's the only thing I can think of now.

\section{Permafrost}

And that's a lotta, land to open up to the sun, I mean, you know, sun melts all that permafrost and never comes back, I guess. 


\section{Drives out mice}

Yep. Because actually, initially it gets poor, for like the first couple of years, because a lot of bears eat mice or shrews. So, you know, those get driven out, you know. Because a lot of fires are ground fires. Those little tiny animals that predators like marten and lynx, and even wolves feed on mice, you know, so until those things start to come back it's kind of like, a poor trapping area.

\section{Hummocks}

So it spoiled a lot of portages because, where we had trails, you know, that, uh, when you got them, right now they call 'em grass hummock you know, and as long as they've got all that grass and stuff there, you can cross 'em pretty easy. But when they are all burned up they're just like a stump stickin' up and you wham and you tip over and, really really hard traveling after that.

\section{Lakes Dry}

Yeah, after the fire wipe them out, come up with more different brush, willow trees, and berries is out in the tundra sometimes, which wipe out all the water, water don't hold any more after it burns. Just make drainage, open up more drainage. We're losing lot of lakes out this way.

\section{Crazy Trees}

You ever notice them, uh, birch trees? They're all, looks like somebody just laid them down. And they're not burnt or anything, I think they're just kind of burnt under the ground.

\section{Fish}

The broth of these little animal. So, I, I ask that, uh, you people study everything on this lake, and I want you to study those big lakes out there, or any place off the flat, where there used to be lots of this kind of fish. And I tell them, I want you to answer if you find what happened, but for one thing, ashes wouldn't, the animal, fish, wouldn't live in ashes. And you know how much ashes come round to these lakes. And just by myself I just think that might, you know. Kill them. Because they have, uh, underground cache. They bury their blueberries in the summer for the winter. With birch bark basket and put cover on it, then they bury it. They get fish eggs, hide it in there, and they sew cover on it for birch bark. And they bury them. Then they, you know, cover it with something, then they cover it. And up on top, they have fire and all the charcoal, and like, all the animal, they don't like charcoal. Because you can't, you know, sniff it. They just keep away from that ashes. And that's why they cover their cache with it. Okay, and, if they do that, then it might affect fish. They have no way to find out. But ashes were, they could, you know. They could try it on fish. See if they live in there. Then they would come back with the answer.

Yeah, he trap there, but the animals would move out of a burned area. 'Cause it's either not cold or they, it's not, it's new to them, or foreign to them or somethin' you know. But maybe it's uh, ash in the ground. But they seem to move away from there and some animals would stay there, but others will move. 